\title{
Can We Trust Consumers With Their Brains? Popular Cognitive Neuroscience, Brain IMAGEs, SELF-HELP AND THE CONSUMER*
}

Tracy D. Gunter**

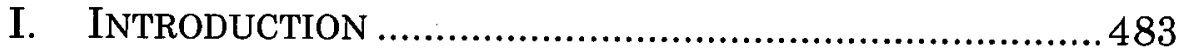

II. The BRAIN's Rise to PRoMINENCE ............................... 486

III. THE BRAIN AS A ROCK STAR .......................................497

IV. The RISE OF the NeUROS AND NeURo SELF-HELP.......503

A. The Market for Brain Self Help Products .............506

B. Examples of Commercial Brain Products..............509

V. BRAin SElF-Help Consumers AND CoNSUMER

PROTECTION .............................................................514

A. Why Protect the Brain Self-Help Consumer?........518

B. Examples of Information Offered to Consumers...523

C. Enhancing Consumer Literacy ............................532

VI. MEChanisms OF CONSUMER PROTECTION ....................537

A. Self-Regulation and Soft Law .............................539

B. Direct Regulation.................................................541

C. CES Devices: An Example of Regulation and

Enforcement .........................................................543

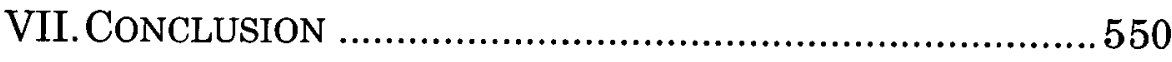

\section{INTRODUCTION}

Cognitive neuroscience captures the imagination by exploring connections between the physical brain and the abstract mind. Through recent advances in functional

* (C) 2014 Tracy D. Gunter. All rights reserved

** Tracy Gunter, M.D., Associate Professor Of Clinical Psychiatry at the IU School of Medicine, Adjunct Professor of Law, Indiana University Robert H. McKinney School of Law, e-mail tdgunter@iupui.edu. I thank research assistants Emily Steeb and Scott Spicer for editorial help and Nicolas Terry for his valuable comments on an earlier draft. 
neuroimaging, the living and acting brain comes to life like never before through vivid pictures. Brain images are seen with regularity in movies, television shows, consumer product advertisements and popular news reports. Against a backdrop of truly exciting brain science, popular rhetoric evokes an illusion that neuroscience has provided a roadmap connecting biology to mentation. ${ }^{1}$ According to popular brain rhetoric, ${ }^{2}$ the active, interconnected, and healthy brain produces an authentic self, and the dimly lit or dysfunctional brain is to blame for unhappiness, failure, and a host of social problems. ${ }^{3}$ The responsible citizen is then tasked with the care and development of the brain, ${ }^{4}$ and many brain self-help products have appeared on the market making claims that they change mental states and abilities by changing the physical brain. ${ }^{5}$

Recent events suggest that brain self-help may not be innocuous. Self-help author James Ray declared that science indicated everything was energy and that all reality was self-generated by the power of the human mind. Although safety and efficacy concerns were raised about his methods as early as 2000 , it was not until three people died and dozens more were hospitalized during a sweat lodge ritual in 2009 that his practice came to a halt. ${ }^{6}$ Concerning foods and supplements, energy drinks promising alertness and focus have now been implicated in dozens of injuries and deaths and herbal remedies have been linked to

1 See Kitty Holman, Coverage of Neuroscience in the Popular Media - The New Psychobabble, Brain Blogger (Mar. 19, 2011), http://brainblogger.com/2011/03/19/coverage-of-neuroscience-in-thepopular-media-the-new-psychobabble, archived at http://perma.cc/5YZCGSSM; David P. McCabe \& Alan D. Castel, Seeing in Believing: The Effect of Brain Images on Judgments of Scientific Reasoning, 107 COGNITION 343, 344 (2008).

2 See generally DAVI JOHNSON THORNTON, BRAIN CULTURE: NEUROSCIENCE AND POPULAR MEDIA (2011).

3 See generally RAYMOND TALLIS, APING MANKIND: NEUROMANIA, DARWINITIS, AND THE MISREPRESENTATION OF HUMANITY (2012).

4 Thornton, supra 2, at 87.

5 See infra Part IV.

6 Craig Harris \& Dennis Wagner, Sweat-Lodge Guru: A Story of Ups, Downs, ARIZ. REPUBLIC, Oct. 23, 2009. 
increases in toxic hepatitis (liver inflammation). ${ }^{7}$ People have also experienced argyria (blue or gray skin caused by silver deposition) and other significant side effects from the ingestion of silver, advertised as a cure-all. ${ }^{8}$ Yet, consumer demand for brain self-help products remains high and is expected to continue to grow. Marketing rhetoric typically attempts to convince self-help consumers that using these products will allow them to outsmart their doctors, foil the pharmaceutical industry, and provide them with risk-free care and enhancement. 9 This situation is far from unique to brain self-help products, but disorders of the brain are common and costly, the level of misinformation and fervor for the subject is high, and the sources of credible information are difficult to locate and navigate.

In this paper I argue that the brain has risen to prominence, that misinformation about the brain has become rampant, and that this misinformation combines with other factors and contributes to consumer susceptibility to the aggressive and misleading marketing of brain-themed products. In the sections that follow, I consider the position of the consumer and protection strategies as they currently exist and conclude with recommendations to improve consumer information in the belief that consumers can be trusted with their brains.

7 Anahad O'Connor, Spike in Harm to Liver Caused by Dietary Aids, N.Y. TIMES, Dec. 22, 2013, at A1; Christine A. Haller, Making a Diagnosis of Herbal-Related Toxic Hepatitis 176 W. J. MED. 39-44 (2002). Energy "Drinks" and Supplements: Investigations of Adverse Event Reports, U.S. FOOD \& DRUG ADMIN. (Nov. 16, 2012), http://www.fda.gov/Food/NewsEvents/ucm328536.htm, archived at http://perma.cc/S55A-JFMU.

8 Stephen Barrett, Colloidal Silver: Risk Without Benefit, QUACKWATCH, http://www.quackwatch.org/01QuackeryRelatedTopics/ PhonyAds/silverad.html (last updated August 17, 2005), archived at http://perma.cc/83VC-5JR2.

9 Stephen Barrett \& William T. Jarvis, How Quackery Sells, http://www.quackwatch.com/01QuackeryRelatedTopics/quacksell.html (last updated Jan. 20, 2005), archived at http://perma.cc/N7JA-XWQK. 


\section{The BRAIN's Rise to PROMinenCE}

People are justifiably hungry for progress in understanding the human brain and behaviors arising from its function. From describing possible biological underpinnings of crime to treating mental illness, advances in brain science have the potential to reduce suffering and save society billions of dollars. Biobehavioral ${ }^{10}$ illness, for example, affects 1.5 billion people worldwide, ${ }^{11}$ accounts for billions of dollars in costs in the United States alone, ${ }^{12}$ and is a leading cause of morbidity worldwide, yet progress in understanding and treating biobehavioral disorders has lagged behind other areas of medicine. ${ }^{13}$ In fact, some scientists and pharmaceutical companies are withdrawing because of the complexity of the field, immaturity of the science, and formidable barriers to the translation of science into effective treatments. ${ }^{14}$ Other researchers and firms are apparently retooling (i.e. moving away from attempting to use traditional pharmaceuticals to effect change in brain

10 In this work, biobehavioral disorders are defined as those disorders involving behavioral signs and symptoms that are inseparable from the biological substrates underlying them. Biobehavioral is an adjective that has been part of the medical literature since the $1970 \mathrm{~s}$ and tends to denote a rejection of mind-body dualism. See generally Kenneth E. Freedland et al., What's in a Name? Psychosomatic Medicine and Biobehavioral Medicine, 71 J. BIOBEHAVIORAL MEDICINE 1 (2009); Alan I. Leshner, Addiction is a Brain Disease, IsSUES IN SCIENCE \& TECHNOLOGY, http://www.issues.org/17.3/leshner.htm (last visited Apr. 3, 2014), archived at http://perma.cc/NAY5-JDMH.

11 LEANNA READ ET AL., BRAIN AND MIND DISORDERS: IMPACT OF THE NEUROSCIENCE 11 (2003).

12 ENITA A. WILlLIAMS, GoOd, BetTer, Best: THE Human QUEST FOR ENHANCEMENT 7 (Mark S. Frankel ed., 2006), available at http://www.aaas.org/sites/default/files/migrate/uploads/HESummaryRep ort.pdf, archived at http://perma.cc/F3K9-98WM.

13 Bruce N. Cuthbert \& Thomas R. Insel, Toward the Future of Psychiatric Diagnosis: The Seven Pillars of RDoC, BMC MEDICINE, May 14,2013 , at 6 .

14 Steven E. Hyman, Psychiatric Drug Development: Diagnosing a Crisis, THE DANA Found. (Apr. 2, 2013), http://www.dana.org/news/ cerebrum/detail.aspx?id=41290, archived at http://perma.cc/MB9ETVBF. 
chemistry and toward the use of neuromodulation devices and genetic technologies to effect change in brain networks).

Attempts to facilitate progress in the area of brain science began more than twenty years ago. President George H. W. Bush proclaimed 1990 through 2000 to be the Decade of the Brain, prioritizing brain research, enhancing public awareness, and encouraging dialogue about emerging discoveries. ${ }^{15}$ Major advances achieved during the Decade of the Brain included recognition of the importance of behavioral genetics, development of brain-computer interfaces, recognition of neurogenesis, and growth of functional magnetic resonance imaging ("fMRI"). ${ }^{16}$ Some credit this as the time period in which mental illness became recognized as a brain disorder. ${ }^{17}$

Although not endorsed as such by the Clinton Administration despite some bipartisan support, the American Psychological Association, in collaboration with more than thirty professional societies, proclaimed 2000 through 2010 to be the Decade of Behavior. This decade focused on the role of behavioral and social science in addressing societal challenges by "promoting a healthier nation, a safer nation, a better educated nation." 18 Lecture series and publications tackled issues such as feminism, racism, sexuality, childhood stress, memory and cognition, sleep, social isolation in health, self-management of chronic

15 Murray Goldstein, Decade of the Brain: An Agenda for the Nineties, 161 W. J. MEDICINE 239, 239 (1994).

16 The Top 10 Discoveries from Decade of the Bram, The Infinite Brain (May 23, 2001), http://www.theinfinitemind.com/mind168.html, archived at http://perma.cc/Y476-CUB9.

17 Thomas R Insel, Understanding Mental Disorders as Circuit Disorders in A Decade After The Decade of the Brain, THE DANA FouND., http://www.dana.org/uploadedFiles/News_and_Publications/ Cerebrum/DecadeAfterDecadeBrainComplete.pdf, archived at http://perma.cc/F72A-YCP6.

18 B. Azar, APA Ushers in the 'Decade of Behavior', 31 MONITOR ON PSYCHOLOGY 10, (2000), available at http://www.apa.org/monitor/jan00/decade-of-behavior.aspx, archived at http://perma.cc/932T-MSLS. 
disease, and public opinion formation and change. 19 Exploring Behavior Week was a specific initiative that provided materials for an encouraged university faculty and students in behavioral sciences to reach out to secondary school students to stimulate interest in the field. ${ }^{20}$

Grass roots groups such as Mental Health America and the National Alliance on Mental Illness have also supported public education about the biological nature of mental illness and research in biobehavioral disorders. ${ }^{21}$ These outreach efforts have likely resulted in increased public support for parity in the treatment of biobehavioral disorders, described by some as the greatest single advance of $2013 .{ }^{22}$

In early 2013, President Obama announced the Brain Research through Advancing Innovative Neurotechnologies ("BRAIN") Initiative as evidence that government is "invest[ing] in the best ideas," 23 and the National Institute of Mental Health announced a decade-long project to develop a research framework based on biological

19 Keren Yairi, Decade of Behavior Moves Onward, 16 PsYCHOL. SCI. AGENDA (2003); Siri Carpenter, Behavioral Science Claims the Decade, 31 MONITOR ON PSYCHOLOGY (2000).

20 Karen Yairi, Decade of Behavior Year Two and Beyond in Division Dialogue Jan 2002 in the section From the Science Directorate, AM. PSYCHOLOGICAL ASS'N (Jan. 2002), http://www.apa.org/about/division/ officers/dialogue/2002/01/science.aspx, archived at http://perma.cc/B6AB$7 \mathrm{CQF}$.

21 Get Info, MENTAL HEALTH AM., http://www.mentalhealthamerica. net/go/information/get-info (last visited Apr. 4, 2014), archived at http://perma.cc/ZHE7-26PJ; About Research, NAT'L ALLIANCE ON MENTAL ILLNESS, http://www.nami.org/template.cfm?section=About_Research (last visited Apr. 4, 2014), archived at http://perma.cc/U959-VLNR.

22 Thomas R. Insel, Director's Blog: Ten Best of 2013, NAT'L INST. of MENTAL HEALTH (Dec. 13, 2013), http://www.nimh.nih.gov/about/ director/2013/ten-best-of-2013.shtml, archived at http://perma.cc/9D2PZF3Y.

23 Barack Obama, U.S. President, 2013 State of the Union (Feb. 12, 2013); see also John Markoff, Obama Seeking to Boost Study of Human Brain, N.Y. TIMES (Feb.17, 2013), http://www.nytimes.com/2013/02/18/ science/project-seeks-to-build-map-of-human-brain.html?smid=pl-share, archived at http://perma.cc/SDH5-HVUR. 
constructs 24 rather than largely subjective symptoms traditionally used in the clinical diagnostic manual, American Psychiatric Association's Diagnostic and Statistical Manual of Mental Disorders, currently in the fifth edition (DSM-5). ${ }^{25}$ The new edition of DSM-5 itself was newsworthy. More than 10,000 public comments were received and reviewed and newspapers such as the Wall Street Journal and New York Times published several articles critiquing the manual before it was generally released. ${ }^{26}$

By the end of 2013 several initiatives were in place with the hope of facilitating brain research by simultaneously improving current understanding of brain anatomy and physiology, developing measurable signs of brain dysfunction and better outlining clinical behavioral phenomenology.

The neurotech industry is worth approximately $\$ 110$ billion, with approximately $\$ 5$ billion in public funding. 27 Groundbreaking advances flowing from this investment are indeed newsworthy. Some recent examples of specific

24 Research Domain Criteria ( $R D O C$ ), NAT'L INST. OF MENTAL HEALTH, http://www.nimh.nih.gov/research-priorities/rdoc/index.shtml (last visited Apr. 4, 2014), archived at http://perma.cc/KA52-HKQY.

25 AM. PSYchiatric Ass'N, Diagnostic AND STATISTIC MaNUAL OF MENTAL DisordERS (5th ed. 2013).

26 Arthur Caplan, Viewpoint: Stop Critiquing the DSM 5, TIME (May 21, 2013), http://ideas.time.com/2013/05/21/viewpoint-stopcritiquing-the-dsm-5/, archived at http://perma.cc/RP5P-UYUY; Paul

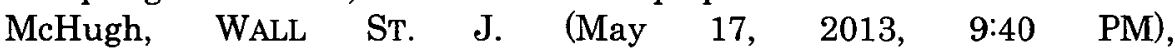
http://online.wsj.com/news/articles/SB1000142412788732421600457848 3391664789414, archived at http://perma.cc/76UT-EERW; Allen Frances, Diagnosing the D.S.M., N.Y. TIMES, (May 11, 2012), http://www.nytimes.com/2012/05/12/opinion/break-up- thepsychiatric-monopoly.html, archived at http://perma.cc/R2SN-S3NP, Sally L. Satel, Why the Fuss Over the D.S.M. -5?, N.Y. TIMEs (May 11, 2013), http://www.nytimes.com/2013/05/12/opinion/sunday/why-the-fussover-the-dsm-5.html, archived at http://perma.cc/JQ6M-727U, Benedict Carey, Psychiatry Manual Drafters Back Down on Diagnoses, N.Y. TIMES (May 8, 2012), http://www.nytimes.com/2012/05/09/health/dsmpanel-backs-down-on-diagnoses.html, archived at http://perma.cc/A9AVLEJ8.

27 WILLIAMS, supra note 12 , at 7. 
innovations in neuroscience include the Human Connectome Project and CLARITY. 28 The Human Connectome Project is a multi-year investment of $\$ 30$ million of public funds with a goal of mapping the human brain using structural and functional magnetic resonance imaging as well as magneto- and electro- encephalography. During 2013, CLARITY scientists discovered how to replace fat in a post-mortem brain with clear plastic to produce a see-through three-dimensional brain that maintains its shape. Advances made during these and other studies will significantly improve the understanding of the brain in illness and in health. As understanding the structure of DNA helped scientists ask better questions about genetic regulation and resulting phenotype, so a better understanding brain structure and function will help scientists ask better questions about neural regulation and resulting attitudes and behaviors.

The task of communicating scientific advances about the human brain to the public is complex, involving journalists, scientists and evolving information systems. While communication patterns between scientists and the media have not changed significantly in many years, the world of public communication has been transformed by online communications. ${ }^{29}$ In the modern world of the internet, scientific, educational and cultural information mix in an environment "dominated by characteristics adapted from

28 THE HUMAN CONNECTOME PROJECT, www.humanconnectome.org (last visited Apr. 4, 2014), archived at http://perma.cc/QU9A-VW2A; The Human Connectome Project: Relating Brain Circuits to Behavior, DAVID VAN ESSEN TEDX TALKS (Jan. 18, 2013), http://tedxtalks.ted.com/video/The-Human-Connectome-Project-Re (last visited Apr. 4, 2014), CLARITY: Hydrogel Process Developed at Stanford Creates Transparent Brain, STANFORD SCH. OF MEDICINE (Apr. 10, 2013), http://med.stanford.edu/ism/2013/april/clarity.html, archived at http://perma.cc/AE4D-WGC9.

29 Hans Peter Peters, Gap Between science and Media Revisited: Scientists as Public Communicators, 10 PROC. NAT'L ACAD. SCI. 14102 (Supp. 2013). 
entertainment, marketing and retailing cultures and media."30

At its best, scientific journalism facilitates the discussion of complex issues such as the public conversation concerning the possible interrelationships between prevalence of firearms, assessment and treatment of mental illness, and violence. At the other extreme are news-like pieces suggesting that people are right- or left- brained, that the brain has a "God spot" and that neuroimaging can read the content of thought. ${ }^{31}$

Because cognitive and social neurosciences strive to "provide neural explanations for basic human behaviors and social norms," advances in this area seem applicable to a wide variety of social issues. ${ }^{32}$ Advances in neuroscience may ultimately challenge some of society's long held assumptions about behavior. ${ }^{33}$ The allure of understanding social convention and human behavior perhaps makes this science particularly prone to sensationalism and speculation. ${ }^{34}$ In concluding a recent study of neuroscience in the popular press, researchers noted that "it seemed clear that research was being applied out of context to create dramatic headlines, push thinly disguised ideological

30 Nicolas P. Terry, Cyber-Malpractice: Legal Exposure for Cybermedicine, 25 AM. J. L. \& MED. 327, 334 (1999).

31 See, e.g., Joe Shute, Are You Right-Brained or Left-Brained, TELEGRAPH (Dec. 13, 2013, 11:55 AM), http://www.telegraph.co.uk/telegraphtv/goodtoshare/10515373/Are-you-right -brained-or-left-brained.html; Jeremy Hsu, Scientists Locate 'God Spot' in Human Brain, FoxNews.com (March 10, 2009), www.foxnews.com/story/2009/03/10/scientists-locate-god-spot-in'humanbrain, archived at http://perma.cc/FXF3-5PMC; Mind-Goggling, ECONOMIST (Oct. 29, 2011), www.economist.com/node/21534748, archived at http://perma.cc/5WMZ-HNC7.

32 Emma Zimmerman \& Eric Racine, Ethical Issues in the Translation of Social Neuroscience: A Policy Analysis of Current Guidelines for Public Dialogue in Human Research, 19 ACCOUNTABILITY IN RES. 27, 28 (2012)

33 Id.

34 Jean Liu, Interactions: The Magic Word is 'Neuroscience', ALTMETRIC (Nov. 30, 2012), http://www.altmetric.com/blog/interactions' the-magic-word-is-neuroscience, archived at http://perma.cc/6A73MPVU. 
arguments, or support particular policy agendas." 35 Although bringing a novel point of view to a discussion may be a reasonable journalistic goal, many scientific experts fear that these misrepresentations of neuroscience may, in fact, slow or stymie true innovation. ${ }^{36}$

However, it would be an error to conclude that the brain's prominence in popular culture arises only from advocacy groups, the popular press and government initiatives. ${ }^{37}$ As innovation has proven difficult and public funding for scientific innovation has plateaued or declined, ${ }^{38}$ scientists have become increasingly responsible for translating their work into public health outcomes and generating money at increasingly early stages in the scientific enterprise. ${ }^{39}$ The use of persuasive discourse in science has, therefore, become much more prevalent, and at least a part of the "hype" generated around biotechnology may come from scientists themselves. ${ }^{40}$

Traditionally, scientists have tended to view communication with the public as distinct from communication within the scientific community. Although some scientists might hype advances, others tend to be ambivalent about involvement with the media. Many scientific experts feel a sense of responsibility to educate the

35 Cliodhna O'Connor et al., Neuroscience in the Public Sphere, 74 NEURON 220, 225 (2012).

36 See Bradley Voytek, A Neuroscientific Renaissance, Oscillatory Thoughts: Thoughts of A NeuRoscientist (July 2, 2011), http://blog.ketyov.com/2011/02/neuroscientific-renaissance.html, archived at http://perma.cc/9VZL-4CVB.

37 See Garret O'Connell et al., The Brain, the Science and the Media, 12 EMBO REP. 630 (2011).

38 See Kenneth D. Harrison et al, Building a Life Sciences Innovation Ecosystem, SCI. TRANSLATIONAL MED., Oct. 24, 2012, at 157.

39 See generally Sarah Zhang, Social Scientists Hit Back at Grant Rules, 503 NATURE 179, 179 (2013); Ahmed Zewail \& Maha Zewail, Science for the "Haves", 52 ANGEWANDTE CHEMIE INT'L EDITION 108 (2013).

40 Zubin Master \& David B. Resnik, Hype and Public Trust in Science, 19 ScI. \& ENGINEERING ETHICS 321, 322-23 (2013).. 
public about important progress in the area, 41 yet frequently have little experience in public communication and fear misrepresentation. 42

Although scientists and journalists both search for truth by analyzing facts, the level of certainty required and means of expression of each are different. Media reporting frequently proceeds from one big headline of an evolving story to the next, while science proceeds incrementally, over long periods of time, arriving at certainty well after the novelty of the initial experiment. ${ }^{43}$ From the perspective of the scientist, dissemination of new information to the public should only occur after scientific goals have been achieved and validated. The process of going from idea to theory to fact is generally reserved for debate within the scientific community. ${ }^{44}$ While scientists and journalists both value being the first to discover something, they cope with it differently. The journalist may value publishing novel, and sometimes speculative, information in public outlets, while the scientist copes by keeping findings private until there is acknowledgement of discovery within the scientific community.

The increase in the engagement and involvement of the public facilitated by popular media may reflect a more general trend toward democratization of neuroscience, which potentially facilitates innovation. Evidence of democratization includes increasing do-it-yourself hobbyists, open access research, published data sets, public

41 The Wellcome Trust, The Role of Scientists in Public Debate, Summary of Findings and ExeCutive Summary, RESEARCH STUDY CONDUCTED BY MORI 3 (2000).

42 See generally RICHARD HAYes \& DANIEL GROSSMAN, A Scientist's Guide to TAlKING WITH THe MEdiA (2006); Joanna M. Wardlaw et al, "Can It Read My Mind?" - What Do Public and Experts Think of the Current (Mis)Uses of Neuroimaging? 6 PLOS ONE, e25829 (2011), http://www.plosone.org/article/fetchObject.action?uri=info\%3Adoi \%2F10.1371\%2Fjournal.pone.0025829\&representation=PDF, archived at http://perma.cc/L3MV-GUHG.

43 JIM HARTZ \& RICK CHAPPELL, WORLDS APART: HOW THE DisTance BETWEEN SCIENCE AND JOURNALISM THREATENS AMERICA'S FUTURE 13 (1998).

44 Peters, supra note 29. 
participation in research design, and crowdsourcing. 45 These signs of a shift to a more open model of the practice of science may result in the emergence of new mechanisms of innovation, along with some likely errors along the way. While some level of hype is a normal and expected part of the development cycle of novel technologies, a middle ground must be found between offering no opinions beyond hard data and exaggerating facts to facilitate wild predictions of an improbable future. Of particular concern is the risk that hype "could result in either premature translation of research or drive the market towards providing unproven or potentially fraudulent treatments to the public." 46

So, what is new about neuroscience? Recent advances in neuroscience bring together the concepts of mind and brain in an unprecedented way. From a scientific standpoint, "the brain is the organ of the mind." 47 This understanding of mind and brain in science dates back to the days of Hippocrates and has been reiterated throughout history. ${ }^{48}$ The scientific desire to localize the physical seat of the mind or soul was largely met with frustration while scientists could only explore the human brain after death and lacked adequate animal models of emotion and cognition.

Mainstream science has embraced a view of the brain as a unique, genetically active tissue that is constantly "on" and multitasking during life. Just as there are no single genes underlying complex biobehavioral disorders, there is no single brain area devoted to complex cognition and decision-making. Modern neuroscience is really about

45 See, e.g., Neuroscience

Attp: Startups, ANGELLIST, https://angel.co/neuroscience (last visited Apr. 5, 2014); see also Neuroscience Research Accelerator, INDIEGOGO, http://www.indiegogo.com/projects/neuroscience-research-accelerator (last visited Apr. 5, 2014).

46 Master, supra note 40.

47 Sunil K. Pandya, Understanding the Brain, Mind and Soul: Contributions from Neurology and Neurosurgery, 9 MENS SANA MONOGRAPHS 129, 139 (2011).

48 Id. 
understanding and embracing complexity, not about modular localization or simplification.

Innovations in neuroimaging have already facilitated a greater understanding of the ways in which brain tumors, injuries and illnesses change brain structure and function, allowing clinicians and researchers to correlate self-reported symptoms with observed areas of dysfunction or injury. Neurosurgical planning is more precise than ever before, and patients facing these procedures are provided with more detailed education about what to expect.

In addition to understanding more about the brain by studying brain illness and injury, researchers also study variations in brain function in groups of healthy study subjects reliably performing specific study procedures to attempt to delineate mechanisms of physical brain function with mental function. 49 fMRI studies combine neuroimaging with behavioral tasks to make inferences about differential activity in brain networks separating the study from control groups. The researcher then has the tasks of defining meaningful change and separating that from random fluctuation within and between the study groups. The researcher must then decide whether the meaningful changes observed between groups may be attributed to the performance of the task.

fMRI measures changes in blood flow and deoxygenated hemoglobin in blood as it circulates through the physical brain at rest and during performance of specified activities. Researchers infer that a transient increase in blood flow with increased concentrations of hemoglobin lacking oxygen

49 See Sally Satel \& ScotT O. Lilienfeld, Brainwashed: THE SEDUCTIVE APPEAL OF MINDLESS NEUROSCIENCE xiv (2013). "The goal of brain imaging is enormously important and fascinating: to bridge the explanatory gap between the intangible mind and the corporeal brain." Id. For further discussion on the topics discussed in the rest of this section, see id. at ch. 1, Taylor, supra, at ch. 14; Nikos K. Logothetis, What We Can Do and What We Cannot Do with fMRI, 453 NATURE REvS. 869 (2008); Nikos K. Logothetis, What We Can Do and What We Cannot Do with fMRI, NATURE: SUPPLEMENTARY INFORMATION, http://www.nature.com/nature/journal/v453/n7197/extref/nature0697 6-s1.pdf, archived at http://perma.cc/XU58-LXB7. 
is an indication of neuronal oxygen use. Further, researchers assume that neuronal communication accounts for the perceived oxygen use. The area of change is then identified as a bright spot. Interpretation of this signal is made more difficult by stray signal or noise that may be picked up during the detection of the signal of interest. Thus, an experiment may be repeated several times in an attempt to identify pertinent signal and separate it from other activity and background noise.

Even with advanced resolution, these "bright spots," measured in voxels on a generated brain image, reflect the function of thousands of neurons and millions of synapses (i.e., connections). An active neuron may increase, inhibit, or modulate regional activity consequently neuronal activity and neurotransmission are not synonymous. Neurons communicate by electrical and chemical mechanisms, which occur at generally faster rates (and thus over a shorter time period) than blood flows and oxygen perfusion changes. In order to further investigate these associations, some research paradigms use both measures of fast-changing brain cell electrical activity such as electroencephalography (EEG) or magnetoencephelography (MEG) and slower changing fMRI to study the complex and interconnected communication systems of the brain. These networks are always "on" and multitasking during life so a "bright spot" is never the only functioning part of the brain, but rather it is a rather large area that is statistically different from the rest.

The fact that the technology has sufficiently progressed so that researchers can see differential activity in a living complex system is amazing, but the perception that these technologies provide transparent windows into humanity and behavior at the level of the individual is grossly inaccurate. ${ }^{50}$ Brain function studies remain relatively gross and indirect measures of how the physical brain works.

50 DAVI A. Johnson, ThE RHETORICAL BRAIN: ARTICULATING Mind AND MATTER IN CONTEMPORARY NEUROSCIENCE 15, 36, 41, 43 (2013), available at https://getd.libs.uga.edu/pdfs/johnson_davi_a_200608_ phd.pdf, archived at http://perma.cc/S26Q-J7JB. 
Similarly, performance on a study task provides incomplete information about how people behave in real-world situations. Additionally, the data produced by these technologies are remarkably complex and the analytic procedures used to generate some of the commonly seen pictures on the internet are based on a number of evolving assumptions. Consequently, drawing conclusions about brain function in everyday life is fraught with difficulty.

The limitations of the science not withstanding, the rhetorical brain is now not only seen as part of the body, but as the seat of humanity (i.e. the individual's thoughts, behaviors, feelings, and decisions). 51 Although some worry that an over-reliance on biological explanations of cognition and emotion will lead to a devaluation of the human experience, ${ }^{52}$ others argue that the drive to know the brain is fundamentally a human pursuit, adding complexity to explanations of human experience and satisfying the human being's deepest curiosity. ${ }^{53}$ While it would be more satisfying to believe that the increases in mentions of the brain in communications and in the public's interest in the brain is driven by a genuine interest in the richness of neuroscientific data and the complexity of the human experience, the reality seems to be that brain rhetoric leverages biological supremacy to serve more proximate goals such as improving the self, differentiating social groups, making products more marketable, making arguments more convincing, and making entertainment more entertaining. ${ }^{54}$

\section{THE BRAIN AS A ROCK STAR}

Just as the number of mentions of neuroscience or the brain has risen dramatically in recent years in news reports

51 Raymond De Vries, Who Will Guard the Guardians of Neuroscience, 8 EUR. MoleCULAR BIology ORG. S65, S65-S69 (2007).

52 See generally TALLIS, supra note 3 ,

53 See generally Pandya, supra note 47.

54 See O'Connor et al., supra note 35, at 225-26. 
and blogs, so the use of brain images has increased in entertainment and advertising.

Movies such as The Brain That Wouldn't Die, Donovan's Brain, Fiend Without A Face, The Man with Two Brains, and The City of Lost Children used bodiless, communicating and sometimes renegade brains as plot elements. ${ }^{55}$ Brainscan is a movie in which a gamer commits murders believed to be part of video game by the same name. ${ }^{56}$ The Exorcist showed a now obsolete brain imaging technology (pneumoencephelography) in the evaluation of the protragonist's behavior changes. ${ }^{57}$ In The Walking Dead, magnetic resonance images of the brain showed black spots, indicating impending zombification. Brain Damage explores addiction through a brain eating reptile that offers the host euphoria in exchange for a steady supply of other human brains. ${ }^{58}$ Inception, Trance, Total Recall, The Bourne Identity, and Eternal Sunshine of the Spotless Mind feature memory alteration. ${ }^{59}$ Limitless and Side Effects use brainaltering medications to advance plots. ${ }^{60}$ Other movies such as Awakenings, The Notebook, Driving Miss Daisy, and $A$ Beautiful Mind explore the, at times, devastating effects of biobhehavioral illness. ${ }^{61}$ Allusions to brain and neurological

55 The Brain That Wouldn't DiE (Sterling Productions 1962); Donovan's BRAIN (Dowling Productions 1953); FRIEND WITHOUT A FACE (Amalgamated Productions 1958); THE MAN WITH Two BRAINS (Aspen Film Society \& Warner Bros. 1983); THE CITY OF LOST CHILDREN (Centre National de la Cinématographique 1995).

56 BRAINSCAN (Admire Productions Ltd. 1994).

57 THE EXORCIST (Warner Bros. \& Hoya Productions 1973).

58 THE Walking DEAD (AMC Studios 2010); BRAIN Damage (Palisades Entertainment Group 1988).

59 INCEPTION (Legendary Pictures \& Syncopy Films 2010); TRANCE (Cloud Eight Films 2013); TOTAL RECALL (Carolco Pictures \& StudioCanal 1990); TOTAL RECALL (Original Film 2012); THE BOURNE IDENTITY (The Kennedy/Marshall Company \& FilmColony 2002); ETERNAL SUNSHINE OF THE SPOTLESS MIND (Anonymous Content \& This is That 2004).

60 Limitless (Virgin Produced et al. 2011); SIDE EFFECTS (Endgame Entertainment et al. 2013).

61 AWAKENINGS (Lasker/Parkes Productions 1990); THE NOTEBOOK (Avery Pix 2004); DrIving Miss DAIsy (The Zanuck Company 1989); A BEAUTIFUL MIND (Imagine Entertainment 2001). 
function can be more subtle. The Scarecrow from The Wizard of $O z$ said that he could be of more help "if I only had a brain." 62 Avatar featured mind-control when the main character guided his flying horse by plugging in his ponytail. 63

Many television shows appealing to all ages feature the brain. Brain of Morbius, a 1976 four-part episode of Doctor Who, centered around the brain of an evil alien kept alive by artificial means. ${ }^{64}$ Star Trek episodes used brain images and mind manipulation on a relatively regular basis. ${ }^{65}$ Two examples are the disembodied brain of Mr. Spock in the episode Spock's Brain from the original series and the rendering helpless of the crew in "The Game" from Star Trek: Next Generation.66 A Friends episode centered on Joey's "new brain."67 Other shows such as The Simpson's and South Park present comic views of this evolving science, with jokes about Homer's brain ${ }^{68}$ and Cartman's V-chip. ${ }^{69}$ The long running television show Pinky and the Brain ${ }^{70}$ portrayed the exploits of two genetically enhanced laboratory mice escaping each night to attempt to take over the world and offered rather detailed information about the brain in "Brainstem" as sung by Brain. ${ }^{71}$ "The Brain

62 THE WIZARD of Oz (Metro-Goldwyn-Mayer 1939).

63 AVATAR (Lightstorm Entertainment et al. 2009).

64 Doctor Who: The Brain of Morbius (BBC television broadcast Jan. 3, Jan. 10, Jan. 17, Jan. 24, 2004). 1987).

65 StaR TREK: The NeXT Generation (Paramount Television

66 Star Trek: The Next Generation: The Game (CBS television broadcast Oct. 26, 1991).

67 Friends: The One with Joey's New Brain (NBC television broadcast Feb. 15, 2001).

68 The Simpsons: Brother from the Same Planet (Fox Broadcasting Company television broadcast Feb. 4, 1993); The Simpsons: HOMR (Fox Broadcasting Company television broadcast Jan. 7, 2001).

69 SOUTH PARK: BIGger, LONGER, AND UNCUT (Paramount Pictures 1999); South Park: I Should Have Never Gone Ziplining (Comedy Central Apr. 18, 2012); South Park: Poor and Stupid (Comedy Central Oct. 6, 2010).

70 Pinky and the Brain: Brainstem (Warner Brothers television broadcast Sept. 17, 1995).

71 Id. 
Surgeon" character was one of the scariest in the hit series Dexter. ${ }^{72}$ CBS aired $3 \mathrm{lbs}$, , a short-lived series about the lives of neurosurgeons. ${ }^{73}$ Perception has recently been renewed for its third season and features an eccentric neuroscientist aiding the FBI in solving of crimes. ${ }^{74}$

Television and movies are not the only sources of brain entertainment. Graphic novels and anime figures also explore themes of brain, brain control, and superiority through brain optimization. ${ }^{75}$ The anime character Neuro, who feeds on the mysteries of the human mind, is a prominent example. ${ }^{76}$ A few examples of brain-themed games include Big Brain Academy, BrainBashers, and Brain Boost. ${ }^{77}$

Turning to popular music, mentions of the brain may reference brain injury, drug use, strong emotion, mental illness, and sociopolitical themes to name but a few references and themes. References to the brain may occur in band names such as Bad Brains and No Brain. Album titles featuring the brain include Emerson, Lake and Palmer's Brain Salad Surgery and Funkadelic's Maggot Brain. ${ }^{78}$ Song titles may also mention the brain. The Ramones song "My Brain is Hanging Upsidedown" describes

72 DEXTER (Showtime Networks et al. 2006).

733 LBS. (The Levinson/Fontana Company 2006).

74 Perception (Paperboy Productions \& ABC Studios 2012).

75 See Phi Brain Anime Gets 3rd Series in 2013, ANIME News NETWORK (Sept. 23, 2012, 8:03 AM), http://www.animenewsnetwork. com/news/2012-09-23/phi-brain-anime-gets-3rd-series-in-2013, archived at http://perma.cc/R22N-PFBF; Brain (Comics), WIKIPEDIA, http://en.wikipedia.org/wiki/Brain_(comics) (last updated Apr. 4, 2014), archived at http://perma.cc/4TD2-HFFB; Brain Boy, WIKIPEDIA, http://en.wikipedia.org/wiki/Brain_Boy (last updated Oct. 4, 2013), archived at http://perma.cc/95QC-NJW6; Professor $X, \quad$ MARVEL, http://marvel.com/universe/Professor_X (last visited Apr. 5, 2014), archived at http://perma.cc/3KQY-JXUC.

76 Neuro Nōgami, WIKIPEDIA, http://nogamineuro.wikia.com/wiki/ Neuro_Nōgami (last visited Nov. 5,2013 ).

77 BIG BRAIN ACADEMY (Nintendo 2005); BRAINBASHERS, http://www.brainbashers.com (last visited Apr. 8, 2014), archived at http://perma.cc/3G4P-V7LW; BRAIN BOOST (Nintendo 2006).

78 EMERSON, LAKE AND PALMER, BRAIN SALAD SURgERY (Manticore Records 1973); FUNKADELIC, MAGgot BRAIN (Westbound Records 1971). 
the intense emotions felt by the narrator during a controversial political event. 79 Green Day's "Brain Stew" describes the narrarator's thoughts and feelings while attempting to fall asleep. ${ }^{80}$ Enigma describes love as "TNT for the Brain." 11 Cypress Hill's "Insane in the Brain" has been described as a "diss" song written after the performers perceived others as not understanding or appreciating their music. ${ }^{82}$ Pink Floyd's "Brain Damage" alludes to mental illness and lobotomy, while Eminem's "Brain Damage" mentions traumatic brain injury and drug use. 83 Stephen Kellogg recently declared, "The Brain is a Beautiful Thing," while exploring sociopolitical themes. 84 Revocation's "The Brain Scramblers" describes a dystopian world in which "[n]neural transformation" produces an untreatable tormented population. ${ }^{85}$ Voltaire and Jonathan Coulton described the thoughts of a zombie in "Brains" and "Re: Your Brains" respectively. ${ }^{86}$ Bob Marley's "Ganja in My Brain," is perhaps the most obvious reference to drug use. ${ }^{87}$

Some consider entertainment devices to be useful in attracting future scientists to the field and creating a "culture of intrigue," which is "where scientific interest and innovation come from." 88 In addition to generally raising

79 The Ramones, My Brain is Hanging Upside Down, on ANIMAL BoY (Beggars Banquet Records 1985).

80 GREEN DAY, Brain Stew, on INSOMNIAC (Reprise Records 1995).

81 ENIGMA, T.N.T. for the Brain, on LE ROI EST MORT, VIVE LE ROI! (Virgin Charisma 1996).

82 CYPRESS HILL, Insane in the Brain, on BLACK SUNDAY (Ruffhouse \& Columbia 1993).

83 PINK FloYd, Brain Damage, on THE DARK SIDE OF THE MOON (Harvest \& Capitol 1973); EMINEM, Brain Damage, on THE SLIM SHADY LP (Aftermath et al. 1999).

84 STEPHEN KellogG, The Brain is a Beautiful Thing, on BLUNDERSTONE ROOKERY (Elm City 2013).

85 REvocATION, The Brain Scramblers, on EXISTENCE IS FUTILE (Relapse Records 2009).

86 Voltaire, BRAINS!, on Boo HoO (Projekt Records 2002); JonATHAN COULTON, Re: Your Brains, on LEFT 4 DEAD 2 (Valve Corporation 2009).

87 RAS MATTHEW, Ganja in My Brain (Creation Sounds 2008).

88 Rachel Rettner, Top Brain Science Movies Revealed, YAHOO NEws (Oct. 3, 2013, 8:55 AM), http://news.yahoo.com/top-brain-science- 
the visibility of the science, some entertainment vehicles deal with brain science in a more serious and accurate way. Examples include of popular television series include the Brain and Behavior Research Foundation's Healthy Minds, National Geographic's Brain Games, Australian television's Redesign My Brain, PBS's Charlie Rose's Brain series, BBC's Brain Story, and the Public Broadcasting Service's Frontline offerings "Brain Wars," "Inside the Teenage Brain," and "League of Denial."89

Recognizing the power of brain images and mentions, industry has reached out to consumers, and their brains, in its own inimitable way. Advertisements for Lego, ${ }^{90}$ cars, ${ }^{91}$ and clean energy products ${ }^{92}$ suggest that the brain prefers these products. PBS wants to expand the brain, not the waist-line;93 Allstate offers insurance to cover adolescents because parts of their brains are missing; 94 and Megacom

movies-revealed-125554655.html, archived at http://perma.cc/7NCWP24M.

89 HEALTHY MINDS (Brain and Behavior Research Foundation 2013); BRAIN GAMES (National Geographic 2011); REDESIGN MY BRAIN (Australian Broadcasting Corporation); THE BRAIN SERIES (Public Broadcasting Service 2010); BRAIN STORY (British Broadcasting Company 2000); Frontline: Brain Wars (PBS television broadcast June 9, 2010); Frontline: Inside the Teenage Brain (PBS television broadcast Jan. 31, 2002); Frontline: League of Denial (PBS television broadcast Oct. 8, 2013).

90 See Lego Print Ads, A Modular LIFE (June 13, 2010, 10:49 PM), https://amodularlife.wordpress.com/2010/06/13/lego-print-ads/, archived at http://perma.cc/J7LL-B32K.

91 See 30 Creative Car Ads, BeAUTIFUL LIFE, http://www.beautifullife.info/ advertisment/30-creative-car-ads/ (last visited Apr. 5, 2014), archived at http://perma.cc/6X3G-T9KZ.

92 See Richard W. Caperton, Everyone Wins With Clean Energy Standards, GRIST (Nov. 30, 2011, 11:00 PM), http://grist.org/energypolicy/2011-11-30-everyone-wins'with-clean-energy-standards/, archived at http://perma.cc/CV9D-GU5C; GENERAL ELECTRIC, www.ge.com (last visited Apr. 5, 2014), archived at http://perma.cc/Q5QU-8NFZ.

93 See, Meghan Young, Brain Boosting Campaigns, TRENDHUNTER MARKETING (Nov. 12, 2011), http://www.trendhunter.com/trends/pbswhere-television-matters, archived at http://perma.cc/BU3H-6H7K.

94 See $A$ Childish View of Risk, RisKologY (Feb. 1, 2011), http://risk-ology.com/2011/02/01/a-childish-view-of-risk/, archived at http://perma.cc/956M-QW9N. 
sells refurbished computers using images of freshly ground brain. ${ }^{95}$ With the ubiquitous presence of mobile computing, people may be exposed to news, entertainment, and marketing materials on an almost constant basis.

\section{THE RISE OF THE NEUROS AND NEURO SELF-HELP}

As a possible side effect of the brain's high visibility, attaching some version of "neuro" to other roots or words has seemingly become a national pastime, and is sometimes called neurofication, ${ }^{96}$ neurohype, and neuromania. ${ }^{97}$ Witty authors wonder whether a neuro-Newton will pave the way to neuro-Nirvana. ${ }^{98}$ Skeptics are now neuroskeptics, ${ }^{99}$ or neurophobes, 100 while proponents are neurohawks, 101

95 See Advertising Agency: “BRAIN" Print Ad by Megacom Advertising, COLORIBUS, http://www.coloribus.com/adsarchive/prints/ advertising-agency-brain-3811405/ (last visited Apr. 5, 2014), archived at http://perma.cc/N9BP-A8SV.

96 Neurofication Definition, UrbanDictionary.com, http://www.urbandictionary.com/define.php?term=neurofication (last visited Apr. 5, 2014), archived at http://perma.cc/7WJL-BDPU.

97 For neurohype, see, e.g., Daniel Carlat, Brain Scans as Mind Readers? Don't Believe the Hype, WIRED MAGAzIne (May 19, 2008), http://www.wired.com/medtech/health/magazine/16-06/mf_neurohacks? currentPage=all; for neuromania, see, e.g., TALLIS supra note 3 , at 5 .

98 See Scicurious, Does Neuroscience Need a Newton?, SCI. AM. (Dec. 3, 2012), http://blogs.scientificamerican.com/scicuriousbrain/2012/12/03/does-neuroscience-need-a-newton/, archived at http://perma.cc/P27Q-TRZS.

99 See Christen Rachul \& Amy Zarzeczny, The Rise of Neuroskepticism, 35 INT'L J. L. \& PsYchIATRY 77 (2012); Alicia Puglionesi, The Seductive Allure of Neuroskepticism, MoTHERBOARD (Jan. 8, 2013, 2:35 PM), http://motherboard.vice.com/blog/the-seductiveallure-of-neuroskepticism, archived at http://perma.cc/DYN5-QYTV.

100 See Neurophobes and Their Neurophobia, PROF ZEKI's MUSINGS (Apr. 6, 2013), http://profzeki.blogspot.com/2013/04/neurophobes“andtheir-neurophobia.html, archived at http://perma.cc/6M89-GU22; Ed Bullmore et al., Why Psychiatry Can't Afford to be Neurophobic, 194 BRIT. J. PSYCHIATRY 293 (2009).

101 See Carl F. Johansson et al., Neurohawks Fight Back, 195 BRIT. J. PSYCHIATRY 268 (2009). 
neurophiles, ${ }^{102}$ neuromaniacal, ${ }^{103}$ or peddling neurotrash. ${ }^{104}$ Fields of study such as neuroeconomics, ${ }^{105}$ neuropolitics, ${ }^{106}$ neurorhetoric, ${ }^{107}$ neuroethics ${ }^{108}$ and neurolaw are now parts of the academic landscape. ${ }^{109}$ Neuromarket researchers may use imaging to identify brain patterns reflecting consumer preferences. ${ }^{110}$ Neurocapital is then generated by

102 See THE NEUROPHILE, http://neurophile.blogspot.com (last updated Oct. 7, 2007).

103 See TALlis, supra note 3, at 5; NATHAN EMMERICH, MEDICAL ETHICS EDUCATION: AN INTERDisCIPLINARY AND SOCIAL THEORETICAL PERSPECTIVE 100 (2013).

104 See Margaret Heffernan, Beware Neurotrash, CBS MONEYwATCH (June 17, 2013, 12:45 PM), http://www.cbsnews.com/8301-505125_16257589570/beware-neurotrash/, archived at http://perma.cc/ZQR6-HVLW; Brigitte Nerlich, Making Neuroscience Public: Neurohype, Neuroscepticism and Neuroblogging; UNIV. OF NotTINGHAM Blogs (May 15, 2012), http://blogs.nottingham.ac.uk/makingsciencepublic/2012/05/15/maki ng-neuroscience-public/, archived at http://perma.cc/M866-KTVA.

105 See Neuroeconomics, DUKE CTR. FOR INTERDISCIPLINARY DECISION SCI., $\quad \mathrm{http}: / / \mathrm{www} . d i b s . d u k e . e d u /$ research $/ \mathrm{d}$ cides/research/neuroeconomics (last visited Apr. 6, 2014), archived at http://perma.cc/DT4U-9PJG; George Loewenstein et al., Neuroeconomics, 59 ANN. REV. PSYCHOL. 647 (2008), available at http://www.annualreviews.org/doi/pdf/10.1146/annurev.psych.59.103006 .093710, archived at http://perma.cc/CSQ9-DT7K; Aldo Rustichini, Neuroeconomics: What Have We Found, and What Should We Search For?, 19 CURRENT OPINION NEUROBIOLOGY 672 (2009).

106 See 23 William E. CONNOlly, TheORY OUT OF Bounds: NeURopolitics: Thinking, CUltuRE, SPEED (2002).

107 See Chris Mays \& Julie Jung, Priming Terministic Inquiry:

Toward a Methodology of Neurorhetoric, 31 RHETORIC REV. 41 (2012).

108 See Walter Glannon, Neuroethics, 20 BIOETHICS 37 (2006); Judy Illes \& Stephanie J. Bird, Neuroethics: A Modern Context for Ethics in Neuroscience, 29 TRENDS NEUROsciEnce 511 (2006); Martha J. Farah, Neuroethics: The Ethical, Legal, and Societal Impact of Neuroscience, 63 ANN. REV. PSYCHOL. 571 (2012).

109 See J. Taylor et al., Neuropsychologists and Neurolawyers, 5 NEURoPSYCHOLOGY 293 (1991); Susan M. Wolf, Neurolaw: The Big Question, 8 AM. J. BIOETHICS 21 (2008).

110 See David Lewis \& Darren Bridger, Market Researchers Make Increasing $U_{\text {se }}$ of Brain Imaging, ADVANCES CLINICAL NEUROSCIENCE \& REHABILITATION, July-Aug. 2005, at 36; Dan Ariely \& Gregory S. Burns, Neuromarketing: The Hope and Hype of Neuroimaging in Business, 11 NAT. REV. NeURoscienCE 284, 284 (2010); Anita Tusche, Neural Responses to Unattached Products Predict Later Consumer 
identifying the brain activity that is associated with consumer preferences. ${ }^{111}$ Neuromyths are perhaps an expected side effect.

Neuromyths are false beliefs about brain function that have become so common that they are no longer questioned. 112 Sometimes the result of misinterpreted, miscommunicated, or obsolete science, neuromyths tend to be repetitive, simple, science-sounding statements that make a case for a specific point of view, product or approach. One common neuromyth is that people have right-brain or left-brain personalities and/or learning styles. The title Left-Brained Larry \& Right-Brained Rachel, the snowboarding movie Left Brain Right Brain, and the Nintendo game Right Brain Left Brain all exploit this common neuromyth. ${ }^{113}$ Another common misconception is that people only use "about 10\%" of the brain. The movie Limitless used the neuromyth of untapped potential in the fictional drug advertisement "Accessing $100 \%$ of your brain is possible."114 Regarding human development, a common neuromyth is that there are windows or critical periods of rapid learning followed by times in which new learning cannot occur, leading people to sometimes expose babies to swimming lessons, classical music, foreign languages and mathematical concepts sometimes before they have the

Choices, 30 J. Neuroscience 8024 (2010); Andrija Javor et al., Neuromarketing and Consumer Neuroscience: Contributions to Neurology, 13 BMC NEUROLOGY (2013), http://www.biomedcentral.com/ content/pdf/1471-2377-13-13.pdf, archived at http://perma.cc/Z9T78TMG.

111 See ACCLAIR, http://www.acclair.co.uk (last visited Apr. 6, 2014), archived at http://perma.cc/W33L-DM2Z.

112 Sanne Dekker et al., Neuromyths in Education: Prevalence and Predictors of Misconceptions Among Teachers, 3 FrONTIERS PSYCHOL. 429 (2012), available at http://www.ncbi.nlm.nih.gov/pmc/articles/ PMC3475349/pdf/fpsyg-03-00429.pdf, archived at http://perma.cc/P8Y6EZC.

113 LeFT-BRAINED LaRRY \& Right BRaIN RACHEL (Sandy A. Ward), available at https://www.youtube.com/watch?v=H4ZPEW1SETc; LEFT BRAIN RIGHT BRAIN (Think Thank 2010); RIGHT BRAIN LEFT BRAIN (Nintendo 2007).

114 LIMITLESS (Virgin Produced 2011). 
ability to sit up in order to make them "smarter."

Neuro self-help is yet another neuro.115 Neuro self-help products are those products made available directly to the consumer to achieve desired "brain" outcomes for themselves. Neuromyths are frequently leveraged by purveyors of neuroproducts in marketing materials, likely due to the simplicity and seeming obviousness of them. Neuro self-help, also referred to as "brain-based selfhelp," 116 puts forth the idea that brainpower is the key to solving a problem or difficulty, frequently going on to assert that increasing brainpower takes effort and new products.

\section{A. The Market for Brain Self Help Products}

While brain self-help products such as Brain Salt ${ }^{117}$ have been parts of our history, the market for these products has experienced double-digit growth rates in recent years, 118 and most recently was estimated to be worth $\$ 11-12$ billion. ${ }^{119}$ The cognitive health food market is worth

115 Neuro Self-Help?, NeURosphere (Aug. 21, 2011), http://neurosphere.wordpress.com/2011/08/21/neuro-self-help/, archived at http://perma.cc/DC8V-W2VK; TNR Staff, Neuro-Self-Help, Dr. Elmo, and a Liberal Legacy: Today's TNR Reader, NEW REPUBLIC (Sept. 26, 2012), http://www.newrepublic.com/article/107733/neuro-self-help-drelmo-and-liberal-legacy-todays-tnr-reader, archived at http://perma.cc/ 52SX-VM7P.

116 Davi Johnson, "How Do You Know Unless You Look?": Brain Imaging, Biopower and Practical Neuroscience, 29 J. MED. HUMAN. 147, 148 (2008).

117 See Ferdinand Meyer V, Francis Newbery \& Sons Brain Salt, PEACHRIDGE GLASS (June 3, 2013), http://www.peachridgeglass.com/ 2013/06/francis-newbery-sons-brain-salt-london/, archived at http://perma.cc/7L9F-T5P8.

118 Melanie Lindner, What People Are Still Willing to Pay For, FORBES (Jan. 15, 2009, 10:45 AM), http://www.forbes.com/2009/01/15/ self-help-industry-ent-sales-cx_ml_0115selfhelp.html, archived at http://perma.cc/U4P4-JCUX.

119 Self-Improvement Market Has Unfilled Niches for Entrepreneurs, PRWEB (Mar. 26, 2012), http://www.prweb.com/ pdfdownload/9323729.pdf. 
another $\$ 2$ billion, ${ }^{120}$ and brain fitness products may add another $\$ 1-2$ billion. ${ }^{121}$ Although the traditional self-help book and workshop market may be decreasing, ${ }^{122}$ every indication is that "functional foods" and brain-training market shares are growing. ${ }^{123}$ Datamonitor predicts that cognitive health foods will grow at more than $10 \%$, outstripping the growth rate of health foods in all other categories. ${ }^{124}$ What follows is a brief overview of the kinds of products available to consumers seeking brain selfimprovement.

Though the self-improvement movement has received significant criticism, ${ }^{125}$ many consider the drive for selfimprovement to be a fundamentally human endeavor. ${ }^{126}$ Self-care has long been part of our history, 127 and healthcare officials point to consumer self-care as "an important part of efficient and effective healthcare delivery." 128 In situations in which consumers have the

120 Elaine Watson, Brain Food Ripe for Growth, But Who Will Lead the Charge? NUTRAINGREDIENTS (May 12, 2011), http://www.nutraingredientsusa.com/Suppliers2/Brain-food-ripe-for-growth-but-who-will-lead-thecharge?utm_source $=$ copyright\&utm_medium $=0$ nSite\&utm_campaign $=$ copy right, archived at http://perma.cc/7R8X-Q456.

121 Omar Ford, Brain Health Market is Expected to Rapidly Grow in Next Decade, MED. DEVICE DAILY (Feb. 12, 2013), http://www.medicaldevicedaily.com/servlet/com.accumedia.web.Dispatch er?next=bioWorldHeadlines_article\&forceid $=81869, \quad$ archived at http://perma.cc/639Q-XNR4.

122 See $\$ 11$ Billion Self-Improvement Market Moves Online, PRWEB (Dec. 1, 2010), http://www.prweb.com/pdfdownload/4847314.pdf.

123 Watson, supra note 120; Ford, supra note 121; Alexandra Posadzki, Brain Fitness Targets Aging Population, WINNIPEG FREE PRESS (Aug. 19, 2013, 1:00 AM), http://www.winnipegfreepress.com/ business/brain-fitness-targets-aging-population-220149541.html, archived at http://perma.cc/J3FZ-JRXX.

124 Watson, supra note 120.

125 See generally Steve Salemo, ShaM: How the Self-HelP MOVEMENT MADE AMERICA HELPLESS (2005).

126 WILLIAMS, supra note 12 , at 8.

127 See generally CHARLES E. ROSENBERG, RIGHT LIVING: AN ANGLOAMERICAN TRADITION OF SELF-HELP MEDICINE AND HyGIENE (Charles E. Rosenberg ed. 2003).

128 Mary Ellen COPELAND, U.S. DeP'T OF HEalth \& Human Servs., Substance Abuse and Mental Health Servs. Admin., 
combination of health literacy and actionable information, self-management of health and wellness are net positives for consumers. The important caveat is that many self-help products make exaggerated or untested claims. ${ }^{129}$ The primary consumer goals for brain self-improvement are rather difficult to quantify, but include self-mastery, selfinvention, effective competition, improved quality of life, and emotional and physical security. ${ }^{130}$

Popular discourse suggests that people must seek more brainpower to be responsible citizens and that neuroscience provides both accessible and actionable information to empower the consumer to meet this responsibility. ${ }^{131}$ Much like attractiveness, it would seem that there is no such thing as too much brainpower (or mental ability as defined by one or more of the following: improved mood, higher intelligence, more efficient organization, greater motivation, intensified concentration, keener memory, increased processing speed, or the heightened ability to perform a new skill) and little objective way of quantifying it. Although maintenance of wellness is frequently touted as a goal of self-improvement, research has shown that those suffering from mental health problems are more likely to turn to complementary or alternative interventions such as those offered by commercial self-improvement products. ${ }^{132}$

RECOVERING Your Mental Health - A SelF-Help Guide, SMA-3504, available at http://store.samhsa.gov/shin/content/SMA-3504/SMA3504.pdf, archived at http://perma.cc/P2TT-KD35.

129 See Ben Martin, The Pros and Cons of Self-Help Books, PSYCH CENTRAL, http://psychcentral.com/lib/the-pros-and-cons-of-self-help-books/ 0001074 (last visited Apr. 6, 2014), archived at http://perma.cc/SA9C-UNS3; Barrie Davenport, 15 Darned Good Reasons Why Self-Help Actually Helps, LIVE BOLD \& BLOOM, http://liveboldandbloom.com/01/life-coaching/15darned-good-reasons-why-self-help-actually-helps (last visited Apr. 6, 2014), archived at http://perma.cc/GR9U-ZWUQ; Jo Ann Oravec, On the "Proper Use" of the Internet: Self-Help Medical Information and On-Line Health Care, 14 J. HEALTH \& SOC. POL'Y 37 (2001).

130 See WILliams, supra note 12 , at $4-8,11$; Johnson, supra note 115 , at 148.

131 See THORNTON, supra note 2, at 109, 161.

132 See generally Tzipi Hornik-Lurie et al., Use of Unconventional Therapies by Primary Care Patients: Religious Resources vs. 
Messages are not all positive, and part of the obligation to enhance the brain flows from the alleged risks in opting out of the enterprise of brain monitoring, training and improvement. ${ }^{133}$ According to popular brain rhetoric, if the concerned consumer does not learn to listen to, use, and respond to the brain, then the individual may fail to realize his or her potential, may make self-defeating decisions, and may even inadvertently damage the brain. ${ }^{134}$

\section{B. Examples of Commercial Brain Products}

Books such as The Better Brain Book, ${ }^{135}$ Change Your Brain, Change Your Life, ${ }^{136}$ and Making a Good Brain Great 137 introduce the reader to the idea that "[y] ou're not stuck with the brain you were born with."138 They might inform the reader that he or she can discover "what your doctor won't tell you about preventing and treating stroke, Alzheimer's, Parkinson's, and other neurological conditions."139 While some offerings tell the reader, "When your brain works right, you work right," 140 others argue

Complementary or Alternative Medicine Services, 21 COMPLEMENTARY THERAPIES MED. 517 (2013).

133 See THORNTON, supra note 2.

134 Id.

135 David Perlmutter \& CARol Colman, THe Better Brain BoOK: THE BEST TOOL FOR IMPROVING MEMORY AND SHARPNESS AND PREventing AgING OF THE BRAIN (2005).

136 Daniel G. Amen, Change Your Brain, Change Your Life: The Breakthrough Program For Conquering ANXIETy, Depression, OBSESSIVENESS, ANGER, AND IMPULSIVENESS (1999).

137 Daniel G. Amen, MaKing a Good Brain Great: The Amen Clinic Program for ACHIEving and Sustaining Optimal MENTAL PERformance (2006) [hereinafter AMEN, MAKING A GoOD BRAIN GREAT].

138 Change Your Brain, Change Your Life: The Breakthrough Program for Conquering Anxiety, Depression, Obsessiveness, Anger, and Impulsiveness, AMAZON.COM, http://www.amazon.com/dp/ $0812929985 / \mathrm{ref}=\mathrm{rdr}$ _ext_tmb (last visited Apr. 6, 2014), archived at http://perma.cc/9MPT-MDYG.

139 The Better Brain Book, Perlmutter Health CTR., http://www.perlhealth.com/books/the-better-brain-book/ (last visited Apr. 6, 2014), archived at http://perma.cc/8VG-J2WK.

140 AMEN, MAKING A GOOD BRAIN GREAT, supra note 137 , at 7. 
"[y]ou are [n]ot [y]our [b]rain."141 Both sides offer plans to help consumers on the one hand improve how the brain works and on the other hand to overcome "[d]eceptive brain messages [that] may be running and ruining your life."142

Foods, drinks and supplements are commonly used to improve a variety of abilities. Drinks such as Neurobliss and Neurogasm (renamed Neuropassion) promise enhancement in a wide range of cognitive and emotional abilities. ${ }^{143}$ Dietary supplements such as vitamins (e.g. A, B, C, D, E), herbs (e.g. ginko bilboa, kava and ginseng) and phospholipids make a variety of claims from preventing cognitive decline to enhancing current mental abilities. Traditional foods that are touted as particularly good for the brain have taken on the moniker "super foods" and include blueberries, avocadoes, and salmon. With names such as Focus Factor, Eureka, Brain Power, Brainalin, and Happy Pills, consumers are barraged with messages that they can feel better and function better without making any other lifestyle choices save taking these pills or eating these foods.

NeuroSky markets the Brainwave Starter Kit and Mindwave Mobile allowing the user to observe electrical patterns with the idea that a watched process is a controllable and/or improved process. ${ }^{144}$ Brain training and fitness programs promise the consumer that by repeating tasks the consumer expands his or her mind by building more, and better, pathways in the brain. ${ }^{145}$ The consumer

141 JeFFrey SCHWARTZ \& REBECCA GLADDING, You ARE NOT YouR BRAIN: THE 4-STEP SOLUTION FOR CHANGING BAD HABITS, ENDING UNHEALTHY THINKING, AND TAKING CONTROL OF YOUR LIFE (2012).

142 Sandra Pawula, You Are Not Your Brain: Book Review, AlWAYS WELL WITHIN (June 13, 2011), http://alwayswellwithin.com/2011/06/13/ you-are-not-your-brain-book-review-and-giveawayl, archived at http://perma.cc/SLP3-MD4E.

143 See, e.g., NEURO, http://drinkneuro.com (last visited Apr. 6, 2014); Jeffrey Klineman, Neuro: No More Gasm, Only Passion, BevNET (Apr. 16, 2012, 11:08 AM), http://www.bevnet.com/news/2012/neuro-nomore-gasm-only-passion, archived at http://perma.cc/8APG-QPAG.

144 See NEUROSKY, http://www.neurosky.com (last visited Apr. 6, 2014), archived at http://perma.cc/G99P-2QW7.

145 See Brain Training Apps, APP CRAWLR, http://appcrawlr.com/iosapps/best-free-apps-brain-training (last visited Apr. 6, 2014), archived 
could also turn to Emotiv for advice, which says, "[y]ou think, therefore, you can." 146 Brain Sync offers the consumer the chance to participate in conscious evolution, ${ }^{147}$ and Immrama helps each person "tap into [his or her] infinite potential."148 Foods, books and supplements to coax the brain into aiding weight loss are also marketed to consumers 149 as are products that allegedly use subliminal signaling to the brain to make the individual more attractive. 150

Although some products are over-the-counter devices, such as the brain stimulation headset that shines light in

at http://perma.cc/FSW7-Z6KB; LUMOSITY, www.lumosity.com (last visited Apr. 6, 2014), archived at http://perma.cc/W3DZ-KNEY; BRAINMATRIX, www.Brainmatrix.com (last visited Apr. 6, 2014), archived at http://perma.cc/7B7Z-MFRS; GAMES FOR THE BRAIN, www.gamesforthebrain.com (last visited Apr. 6, 2014); Andrew J. Latham et al., The Virtual Brain: 30 Years of Video-Game Play and Cognitive Abilities, Frontriers Psychol.,, Sept. 2013; Brain Fitness Program, POSIT SCI., http://www.positscience.com/brain-trainingproducts/brain-fitness-program (last visited Apr. 6, 2014), archived at http://perma.cc/46BA-FSYY; Brain Fitness, BRAIN MATRIX, http://www.brainmetrix.com/brain-fitness/ (last visited Apr. 6, 2014), archived at http://perma.cc/JKF8-RPMR.

146 EMOTIV EPOC, http://www.emotiv-epoc.de (last visited Apr. 6, 2014), archived at http://perma.cc/APW2-CMLK.

147 BRAIN SYNC, http://www.brainsync.com (last accessed Apr. 6, 2014), archived at http://perma.cc/NM5F-KRNH.

148 Infinity Program with Gentle Rain (MP3), IMMRAMA INST., http://www.immrama.org/productcart/pc/viewPrd.asp?idproduct=32\&idc ategory=\#details (last visited Apr. 6, 2014), archived at http://perma.cc/43DN-4KQT.

149 See Daniel G. AMEn, The Amen Solution: The Brain Healthy Way to GeT ThINNER, SMARTER, HAPPIER (2011); DANIEL G. AMEN, Change Your Brain, Change Your Body: UsE Your BraIN To GET AND KEEP THE Body You Have AlWays Wanted (2010); Brain-Based Weight Loss, JAUDY TREATMENT CTR., http://www.drjaudy.com/brain-basedweight-loss/ (last visited Apr. 6, 2014), archived at http://perma.cc/W3CF-JNQJ; Weight Management, MIND WoRKS, http://store.amenclinics.com/supplements/weight-management/ (last visited Apr. 6, 2014), archived at http://perma.cc/7AMC-YF7R.

150 INCREASE YOUR SEX APPEAL: COMBINATION OF SUBLIMINAL \& Learning While Sleeping Program (2013); Becoming A Master SEDUCER (2012). 
the ears to lessen sad moods ${ }^{151}$ or the do-it-yourself neural stimulator made available to satisfy consumer curiosity about their own brains, ${ }^{152}$ some brain-themed commercial self-improvement products, such as cranial electrotherapy stimulation ("CES") devices, require a prescription in the United States. ${ }^{153}$ Retailers may sell products directly to consumers from international websites ${ }^{154}$ or provide a professional to write the required prescription, ${ }^{155}$ offering a path directly to consumers and evading traditional regulation.

Today's consumer receives messages about products that reportedly enable him or her to "think smart," 156 play the brain, ${ }^{157}$ power up the brain, ${ }^{158}$ use the brain to control

151 See VALKEE.COM, http://valkee.com/en/ (last visited Apr. 6, 2014), archived at http://perma.cc/DKT2-7L2T.

152 See Nancy A. Melville, DIY Brain Stimulation Raises Concerns, MEDSCAPE (July 10, 2013), http://www.medscape.com/viewarticle/ 807593.

153 Though the intent of this protection was to insure that a consumer-selected provider was involved in the determination of the appropriateness of the device for the individual consumer, the manufacturer or marketer may offer consumers the opportunity to have a prescription written for them using an online provider and usually for an additional fee.

154 See, e.g., SOTA, http://www.sota.com (last visited Apr. 6, 2014), archived at http://perma.cc/867B-97KK.

155 Frequently Asked Questions, How to Buy a Device, Fisher Wallace Simulator ${ }^{\circledR}, \mathrm{http}: / / \mathrm{www}$.fisherwallace.com/cranial-stimulatorfaq (last visited Apr. 6, 2014).

156 See RICHARD RESTAK, THINK SMART: A NEUROSCIENTIST'S PRESCRIPTION FOR IMPROVING YOUR BRAIN's PERFORMANCE (2010); THINK SMART for Aptitudes, WINDOWS, http://apps.microsoft.com/ windows/en-us/app/think-smart-for-aptitudes/c15e7514-569c-4359-a88b0b50394b65f9 (last visited Apr. 6, 2014); Stay Calm and Think Smart, THE KEEP CALM-o-MATIC, http://www.keepcalm-o-matic.co.uk/p/staycalm-and-think-smart/ (last visited Apr. 6, 2014), archived at http://perma.cc/HWG4-2URC.

157 See ANETTE PREHN \& KJELd Fredens, Play Your Brain: AdoPT A Musical MindseT AND CHANGE YOUR LifE AND CAREER (2012).

158 See DAVId PERLMUTTER \& Alberto VILLOLdO, POWER UP Your BRAIN (2011). 
things 159 and even outsmart the brain. 160 Products reportedly developed by physicians, mental health providers, researchers, and others claim to calm the brain, 161 enhance mood, 162 improve focus, 163 improve thinking 164 and induce weight loss. ${ }^{165}$ If the consumer conceptualizes the brain as lazy or out of shape, products are available to balance ${ }^{166}$ and exercise the brain to feel better than ever, prevent decline and become smarter. 167

159 See Brain Controllers, BIOTELEMETRICA, http://biotelemetrica. pbworks.com/w/page/14815320/BrainController (last visited Apr. 6, 2014), archived at http://perma.cc/WNH2-6BPN.

160 See OUTSMART YOUR BRAIN, http://outsmartyourbrain.com (last visited Apr. 6, 2014), archived at http://perma.cc/LQ3E-8XYH.

161 See Brain Calmers, MINDWORKS, http://store.amenclinics.com/ supplements/gaba-calming-support (last visited Nov. 9, 2013), archived at http://perma.cc/54BH-MEH4.

162 See Mood Support, MINDWoRKS, http://store.amenclinics.com/ supplements/mood-support/ (last visited Apr. 6, 2014), archived at http://perma.cc/3297-S7EP.

163 See Brain Focus, MINDWORKS, http://store.amenclinics.com/ supplements/brain-focus/ (last visited Apr. 6, 2014), archived at http://perma.cc/Z54P-DM3S.

${ }_{164}$ See Total Health Network - Brain Support, TOTAL HEALTH DISCOUNT VITAMINS, http://www.totaldiscountvitamins.com/product/ 25957/total_health_brands (last visited Apr. 6, 2014), archived at http://perma.cc/R5LK-PE9X; Cerebrate, 4 ORGANICS, http://organicsmanufacturer.com/memory-booster-brain-health.php (last visited Apr. 6, 2014), archived at http://perma.cc/LDE9-DU9H.

165 See GEORgIA D. ANDRIANOPOULOS, RETRAIN YOUR BRAIN, RESHAPE YOUR BODY: A BREAKTHROUGH BRAIN-CHANGING WEIGHT-LOSS PLAN (2007); JENNIFER JOLAN \& RICH BRYDA, BRAIN CONTROLlED Weight Loss: The Solution to Falled DiETs \& Exercise Programs (2012).

166 See Jay Lombard ET AL., Balance Your BRAin, BaLANCE Your LIFE: 28 DAYs To FEeling BetTer Than You Ever HaVe (2003); How to Balance Your Cortices, BODY TALK SPACE, http://bodytalkspace.wordpress.com/media/support/how-to-balance-yourcortices-your-brain/ (last visited Apr. 6, 2014); RESTORATIVE MINDS, http://www.restorativeminds.com (last visited Apr. 6, 2014), archived at http://perma.cc/G4E7-V3JR.

167 See Scott Cram, Train Your Brain and Entertain, LYBRARY.COM, http://www.lybrary.com/train-your-brain-and-entertain-p-379.html (last visited Apr. 6, 2014), archived at http://perma.cc/5QM8-QK95; Brain 
Parents and care providers are told that they can also improve the brains of the next generation-children's brains. ${ }^{168}$

\section{BRAIN SELF-HelP CONSUMERS AND CONSUMER PROTECTION}

Although brain themed products are common, not all brain themed products are brain self-help products. Examples of brain themed products that would not be considered self-help products include technologies using a simplistic brain computer interface to guide figures in a video game or control a mobile device. Similarly, using brainwaves for matchmaking would not be a brain self-help product. ${ }^{169}$ Though likely perceived of as more credible than they are to consumers owing to neuromyths, these products do not claim to alter brain function or improve the brain.

The focus of this discussion is on technologies making brain improvement claims. Examples include devices that encourage consumers to visualize brain waves and draw conclusions about mental states. Brain exercising games propagate the brain-as-muscle neuromyth and make claims of improving memory, cognition, decision-making, and behavior due to alteration in brain function. These, along

Training, BRAIN METRIX, http://www.brainmetrix.com (last visited Apr. 6, 2014), archived at http://perma.cc/W8P8-D6VY.

168 See Michael Scanlon, Brain Training for Kids, LuMosity BLOG (May 14, 2008), http://www.lumosity.com/blog/brain-training-for-kids/; Fun Brain Training for Children, MIND SPARKE, http://www.mindsparke.com/fun_brain_training_focus_booster.php (last visited Apr. 6, 2014), archived at http://perma.cc/LRA5-X3A6; Focus Pocus, NEURO SKY (Aug. 25, 2011), http://press.neurosky.com/PDFs/ FocusPocus-FactSheet.pdf, archived at http://perma.cc/942Z-8XYM.

169 See Dating Website Examines Brainwaves to Find Better Matches, NeUROGADGET.COM (Feb. 14, 2011), http://neurogadget.com/ 2011/02/14/dating-website-examines-brainwaves-to-find-bettermatches/296, archived at http://perma.cc/X2CG-Z6N8; Andreas Bartels \& Semir Zeki, The Neural Basis of Romantic Love, 11 NEUROREPORT 3829 (2000); Jeffrey C. Cooper et al., Dorsomedial Prefrontal Cortex Mediates Rapid Evaluations Predicting the Outcome of Romantic Interactions, 32 J. NEUROSCIENCE 15,647 (2012). 
with seminars, books, foods, and supplements making similar claims, are considered brain self-help products in this discussion.

Consumer demand for brain self-help products is high and expected to continue to grow at record rates. 170 Consumers generally believe that they have at least a relative safety net ${ }^{171}$ when shopping for products in the marketplace because of extensive consumer rights and protections that exist through regulation. ${ }^{172}$ The FDA in

170 See Kerry Watson, Cognitive Health Ingredients Drive Category Growth, NATURAL PRODUCTS INSIDER (June 25, 2013), http://www. naturalproductsinsider.com/articles/2013/06/cognitive-health-ingredientsdrive-category-growt.aspx, archived at http://perma.cc/7YBB-EG7D; see generally Tyson Greer, The US Consumer Market for Brain Fitness Applications: 2009-2014 Forecast and Analysis, AMBIENT InsIGHT TARGETED RESEARCH REPORT (April 2010), http://ambientinsight.com/ Resources/Documents/AmbientInsight_2009_2014_USConsumerBrainFitn ess_ExecOverview.pdf, archived at http://perma.cc/VMJ7-XJDL.

171 Glenn Kaplan, Patching the Holes in the Consumer Product Safety Net: Using State Unfair Practice Laws to Make Handguns and Other Consumer Goods Safer, 17 YALE J. ON REG. 2 (2000); see also, e.g., World's Food Standard Body Praised as Safety Net for Consumers, FooD AND AGRIC. ORG. OF THE U.N. (July 2, 2013) http://www.fao.org/news/story/en/item/ 179340/icode/, archived at http://perma.cc/9AVA-QJVT; Solange HelinVilles, A Stronger Safety Net for European Consumers, SocIaLISTS \& DEMOCRATS (Oct. 17, 2013), http://www.socialistsanddemocrats.eu/ newsroom/stronger-safety-net-european-consumers, archived at http://perma.cc/9B4S-QF4C; Stephen Koff, Consumer Safety Net has Frayed, CleVELAND.COM (Apr. 6, 2008, 8:00 PM), http://blog.cleveland.com/ openers/2008/04/_washington_last_halloween.html, archived at http://perma.cc/GZK2-FVD8; Protecting, and Mending, Our Consumer Safety Net, COURANT (Nov. 4, 2007), http://articles.courant.com/2007-1104/business/0711030002_1_publisher-of-consumer-reports-consumersunion-food-safety, archived at http://perma.cc/YFY9-TATT.

172 John F. Kennedy, Special Message to the Congress on Protecting the Consumer Interest, THE AMERICAN PRESIDENCY ProjECT (Mar. 15, 1962), http://www.presidency.ucsb.edu/ws/?pid=9108, archived at http://perma.cc/X74C-H83X; see Consumer Rights, Consumers INT'L, http://www.consumersinternational.org/who-we-are/consumer-rights (last visited Apr. 7, 2014), archived at http://perma.cc/C7R4-3EVF; Robin Brown, The U.N. Guidelines for Consumer Protection: Making Them Work in Developing Countries, in CONSUMERS IN THE INFORMATION SOCIETY: ACCESS, FAIRNESS AND REPRESENTATION (2011); Mary Lush \& Val Hinton, Consumer Bill of Rights, in ENCYCLOPEDIA OF 
fact states as one of its goals "to build a public health safety net for consumers around the world." 173

Yet most, if not all, brain self-improvement products arrive on the market without particularly rigorous testing regarding claims made. Repeated controversies such as cereals claiming cognitive enhancement, ${ }^{174}$ weeds found in herbal supplements, ${ }^{175}$ and deaths following use of energy drinks marketed to the young are but a few examples of how this proverbial safety net fails to meet consumer expectations of protection. ${ }^{176}$ The reality is that the individual consumer is responsible for discovering and weighing risks and benefits associated with the use of the products because investigations occur after reports of dissatisfaction or adverse events.

Though there have been repeated attempts by producers and marketers to cast biological information and

BUSINESS AND FINANCE (Burton S. Kaliski eds., 2d ed. 2007); U.N. COMM'N ON SUSTAINABle Dev., CONSUMER Protection AND SUSTAINABle CONSUMPTION: NeW GUidelines FOR THE Global CONSUMER (1998).

173 Global Initiative, U.S. FOOD AND DRUG ADMINISTRATION, http://www.fda.gov/AboutFDA/Globallnitiative/ (last updated Dec. 18, 2013), archived at http://perma.cc/EDP7-5NPV.

174 Kellog Settles FTC Charges That Ad's for Frosted MiniWheats were False, FED. TRADE COMM'N (Apr. 20, 2009), http://www.ftc.gov/news-events/press-releases/2009/04/kellogg-settles-ftccharges-ads-frosted-mini-wheats-were-false, archived at http://perma.cc/BYS7-W32P.

175 Mary Beth Quirk, Testing Reveals Weeds And Rice Fillers Where The Herbs Should Be In Herbal Supplements, THE ConSUMERIST (Nov. 4, 2013), http://consumerist.com/2013/11/04/testing-reveals-weedsand-rice-fillers-where-the-herbs-should-be-in-herbal-supplements, archived at http://perma.cc/A9-D7TT.

176 Energy "Drinks" and Supplements: Investigations of Adverse Event Reports, U.S. FoOD AND DRUG ADMIN. (Nov. 16, 2012), http://www.fda.gov/Food/RecallsOutbreaksEmergencies/SafetyAlertsAdv isories/ucm328536.htm, archived at http://perma.cc/TC2X-WCTT; Letter from Edward Markey, U.S. Senator, John D. Rockefeller, U.S. Senator, Richard J. Durbin, U.S. Senator, and Richard Blumenthal, U.S. Senator, to Scott Henderson, President Living Essentials (Sept 25, 2013) available at http://www.markey.senate.gov/documents/2013-0925_5hr.pdf, archived at http://perma.cc/JRT7-QB7E. 
manipulation of the brain as entertainment, 177 the promise of changing or improving the physical brain is at the heart of most advertised benefits in brain self-improvement. Looking for health information is in fact a common online activity. Eight in ten internet users have looked online for health information, ${ }^{178}$ and there are health claims contained in the advertising of many neuro self-help products.

A recent Google search of "brain health" returned $930,000,000$ results in 0.26 seconds. The search screen featured more than eleven advertisements for brain training games and supplements on the banner and side bar, with only a few mentions of information from noncommercial entities. One game specifically states that individuals with attention deficit hyperactivity disorder benefit from using this game, loosely based on EEG

177 See generally Imran Khan, Spit Parties: Genetic Testing Becomes a Social Activity, The GUARDIAN (Sept. 18, 2008, 6:52 AM), http://www.theguardian.com/science/blog/2008/sep/18/genetic.testing, archived at http://perma.cc/6PNE-Q9VG; Party Till You Spit, THE 23 AND ME BLOG (Dec. 4, 2007), http://blog.23andme.com/news/inside23andme/party-till-you-spit/, archived at http://perma.cc/7NEH-9HU9; Jess Zielinski, 'Spit Parties': You Want a Genetic Test With Your Cocktail?, USA TODAY (Sept. 16, 2008, 11:27 AM), http://content. usatoday.com/communities/sciencefair/post/2008/09/779570/1\#.UpdvdaU 4T1p, archived at http://perma.cc/EJ5Y-LXKD; Steven Novella, Brain Stimulation for the Masses, SCIENCE-BASED MEDICINE (July 10, 2013), http://www.sciencebasedmedicine.org/brain-stimulation-for-the-masses/, archived at http://perma.cc/UZ2T-KD4Q; Einstein Brain Trainer, BBG ENTERTAINMENT, http://www.bbg-entertainment.com/games/einsteinbrain-trainer (last visited Apr. 7, 2014), archived at http://perma.cc/6T5L-NETQ; GoFLOW, http://flowstateengaged.com (last visited Apr. 7, 2014); Christopher Mims, DIY Kit Overclocks Your Brain With Direct Current, MIT TECH. REVIEW (Mar. 8, 2012), http://www.technologyreview.com/view/427177/ diy-kit-overclocks-yourbrain-with-direct-current/, archived at http://perma.cc/ZP2A-E5CP.

178 Susannah Fox, Health Topics: 80\% of Internet Users Look for Health Information Online, PEW RESEARCH CTR. (Feb. 1, 2011), available at http://www.pewinternet.org/ /media//Files/Reports/2011/ PIP_Health_Topics.pdf, archived at http://perma.cc/98KP-VKMH; see generally Susannah Fox \& Maeve Duggan, Health Online 2013, PEW RESEARCH CTR. (Jan. 15, 2013), available at http://www.pewinternet.org/ $\sim /$ media//Files/Reports/PIP_HealthOnline.pdf, archived at http://perma. cc/H6R9-FZNK. 
technology. ${ }^{179}$ This tie between implied health information and brain products allegedly "not designed or intended to diagnose or treat health problems" is not subtle. When looking at credible sources of consumer friendly brain information, the Dana Foundation brain health information did not appear until the third search screen, the first result referencing the National Institutes of Health was on the fifth page of search results, and the first Centers for Disease Control reference was on the seventh page of search results. The vast majority of the initial 100 search results were for various commercial brain self-help products.

\section{A. Why Protect the Brain Self-Help Consumer?}

To the degree that the rational consumer has a selfidentified need that an available technology can meet, understands the technology and its risks, has access to the technology, is prepared for the associated outcomes and has the resources to buy the product, a consumer rights model would suggest that he or she should be able to do so with the comfort that marketplace regulation will provide fair competition and the free flow of truthful information in the marketplace. 180

Behavioral economics suggests that consumers are however not always rational actors. ${ }^{181}$ Consumers may be vulnerable as the result of temporary or permanent individual life circumstances such as youth, illness, infirmity, and illiteracy. ${ }^{182}$ As previously noted, people in distress and those with mental illness were more likely to seek alternative therapies, and thus there are particular areas of concern around brain self-help. Market factors

179 Focus Pocus, NeURo SKY (Aug. 25, 2011), http://press.neurosky.com/PDFs/FocusPocus-FactSheet.pdf, archived at http://perma.cc/6M4Q-NLW3.

180 See Consumer Rights, supra note 172.

181 CASs R. Sunstein \& Richard H. ThaleR, Nudge (2009); Peter A. UbEL, FreE MaRKET MadNESS: Why HuMAN NATURE IS AT ODDS With ECONOMICS-AND WHY IT MATTERS (2009).

182 ECCG Plenary, European Consumer Consultative GrouP OPINION ON CONSUMERS AND VIABILITY (2013). 
such as information asymmetry, supplier exploitation, and complex products may contribute to consumer vulnerability, as can limitations in environments and alternative products and services. 183 Social factors such as exclusion and isolation may also increase consumer vulnerability. ${ }^{184}$ Even consumers who might not otherwise be considered vulnerable respond to group pressure, suggestion, and faulty cause and effect associations seen in many advertisements.

Although there is a strong desire for science and health news, both scientific and health literacy have been identified as major challenges facing U.S. consumers. ${ }^{185}$ Trust appears to play at least as prominent a role as factual knowledge in public understanding and acceptance of novel technologies. ${ }^{186}$ Studies have also indicated that consumers were easily misled by neuroscience jargon, elaborate brain pictures, and reductionistic explanations. ${ }^{187}$ Consumers also tend to approve of perceived medical uses of neuroscientific technologies ${ }^{188}$ and may be relatively less critical when products appear to be health products. Further, consumers tend toward products that promise them "real" change with a minimum of effort and

$183 I d$.

$184 I d$.

185 See generally SATEL \& LILIENFELD, supra note 49; HARTZ \& CHAPPELL, supra note 43; Donald Kennedy \& Geneva Overholser, Science and the Media, AM. ACAD. OF ARTS \& SCI. 27-28, http://amacad.org/pdfs/scienceMedia.pdf, archived at http://perma.cc/779A-PJXM; MARK KUTNER ET AL., THE HEALTH LITERACY OF AMERICA's ADULTS: RESULTS FROM THE 2003 NATIONAL AsSESSMENT OF ADULT LiTERACY, NAT'L CENTER FOR EDUC. STAT. (2006); The Brain and the Public: Q\&A with Susan G. Amara, President, the Society for Neuroscience, THE KAVLI FouND., http://www.kavlifoundation.org/science-spotlights/sfn-amara-int (last visited Apr. 7, 2014), archived at http://perma.cc/8BQ7-W9YD.

186 Zubin Master \& David B. Resnik, Hype and Public Trust in Science, 19 SCI. \& ENGINEERING ETHICS 321 (2013).

187 Tulpesh Patel, Article for Argument: Don't Believe the Neurohype, ScICоммвовULATE (Mar. 6, 2013, 7:54 PM), http://scicommbobulate.blogspot.com/2013/03/article-for-argument-dontbelieve-neuro.html, archived at http://perma.cc/ACC6-6P9K.

188 See generally Wardlaw et al., supra note 42 , at 3. 
commitment. The vulnerability of the consumer to this convenience factor is well known to marketers. ${ }^{189}$

In the age of neuromania, or neurohype, misinformation about brain science comes from news reporting, entertainment, testimonials, and blogs in addition to product placements and advertisements. While not unique to neuroscience, false positive study results abound, and little explication of study design and limitations is seen in the popular media. ${ }^{190}$ Thus, the reliable information available to even the savviest of consumers is limited.

In general, consumers tend to be overly confident and overly optimistic. 191 Just as trust plays a significant role in the understanding and acceptance of biotechnology, so it does in product acceptance. Consumers are frequently unaware of the degree to which there is purposeful exploitation of their biases. ${ }^{192}$ For instance, there is a strong tendency for people to accept things when told that many other people accept them, so advertisers may well use language to suggest that product use or benefit is occurring in large groups of people. People also tend to identify with other people like them in some ways so testimonials may be used to facilitate this identification. ${ }^{193}$ There are also

189 See, e.g., W. Thomas Anderson, Jr., Identifying the Convenience-Oriented Consumer, 8 J. MARKETING RES. 179, 179-83 (1971); Lew G. Brown, The Strategic and Tactical Implications of Convenience in Consumer Product Marketing, 6 J. Consumer MARKETING 13, 16.18 (1989); Eugene J. Kelley, The Importance of Convenience in Consumer Purchasing, 23 J. MARKETING 32, 32 (1958).

190 John P. A. Ioannidis, An Epidemic of False Claims: Competition and Conflicts of Interest Distort Too Many Medical Findings, SCI. AM. (May 17, 2011), http://www.scientificamerican.com/article.cfm?id=anepidemic-of-false-claims, archived at http://perma.cc/UR3V-5NEC; Wardlaw et al., supra note 42 , at 1 .

191 SUNSTEIN \& THALER, supra note 181, at 31-33.

192 See generally SUNSTEIN \& THALER, supra note 181; see generally UBEL, supra note 181.

193 See generally Lumosity Human Cognition Project, http://www.lumosity.com/ (last visited Mar. 19, 2014), archived at http://www.lumosity.com/ (claiming to have 50 million members from over 182 countries, and picturing people of diverse characteristics with the claim: "Our members are amazing athletes, talented artists, and 
tendencies to draw similarities between imagined and actual experiences, particularly those events occurring proximate in time, so advertising language is frequently broad and descriptive of common events. As brain images and scientific language become increasingly prevalent in news and entertainment, commercial vendors may borrow this language to engender trust and familiarity.

Consumers frequently assume that knowledge gained from the news media, combined with marketplace assurances of product safety and provision of sound information, provide a basis on which to make brain selfhelp product decisions. ${ }^{194}$ Not unsurprisingly, studies confirm that media reporting "moderates differences between the public and experts" regarding appropriate uses of brain technologies. ${ }^{195}$ There are also no easily identifiable major aggregators of consumer feedback regarding brain self-improvement products or of balanced research findings related to these products to assist the consumer who might search for information about them.

Consumers do not tend to reason that any and all interactions with the environment change blood flow and brain activity on a continuous basis, so claims about a product changing the brain do not appear as obviously flawed, or even comical, to the casual consumer as they frequently do to practitioners and scientists. Although neuroscience is in its infancy, and there is significant scientific indeterminacy in many areas, there are frankly preposterous claims ${ }^{196}$ that should be readily identifiable as such by regulatory bodies and the truly empowered consumer.

hard-working parents. But no matter where they come from, they can challenge their brains with Lumosity.").

194 See generally Paul D. Nussbaum, Brain Health: Bridging Neuroscience to Consumer Application, 35 GENERATIONS J. AM. SOC'Y ON AGING 6 (2011).

195 O'Connell et al., supra note 37 , at 634 .

196 See Molly Crockett, Beware Neuro-Bunk, TEDSALON (Nov. 2012), http://www.ted.com/talks/ molly_crockett_beware_neuro_bunk.html?quote=1991. 
At its best, marketing has the goal of matching safe and effective products with the consumer seeking them. However, manipulative advertising and disease mongering are also real phenomena. ${ }^{197}$ Consumers may be influenced by suggestions of a starting point for their thoughts about a matter, capitalizing on or pathologizing common occurrences, framing effects, appeals to loss aversion, and pointing to similar (even if infrequent) situations. ${ }^{198}$ For example, consumers may be influenced to believe that they have a need based on advertisements that define common normal variations in function as indications of disease or equate risk factors and disease states. 199 The advertisements then typically ascribe negative emotion or suffering to this state of less than optimal functioning. Manipulative advertisers may also misuse statistics to exaggerate frequency of the need. ${ }^{200}$ The advertisements then go on to idealize product effects, set vague endpoints for product use, and tell the consumer that he or she will function at a higher level if this need (dysfunction, difficulty, or disease) is corrected. This type of manipulative advertising is sometimes referred to as disease mongering. ${ }^{201}$ Manipulative advertising underestimates

197 See Ray Moynihan \& David Henry, The Fight Against Disease Mongering: Generating Knowledge for Action, 3 PLOS MED. e191 (2006), http://www.plosmedicine.org/article/fetchObject.action?uri=info\%3Adoi\% 2F10.1371\%2Fjournal.pmed.0030191\&representation=PDF, archived at http://perma.cc/76HM-MW4J; Barbara Mintzes, Disease Mongering in Drug Promotion: Do Governments Have a Regulatory Role? 3 PLoS MED. e198 (2006), http://www.plosmedicine.org/article/ fetchObject.action?uri=info\%3Adoi\%2F10.1371\%2Fjournal.pmed.003019 8\&representation=PDF, archived at http://perma.cc/M2MQ-7R8M.

198 See generally DANIEL KAHNEMAN, THINKING, FAST AND SLOW (2013); SUNSTEIN \& THALER, supra note 181; UBEL, supra note 181.

199 Ray Moynihan et al., Selling Sickness: The Pharmaceutical Industry and Disease Mongering, 324 BMJ 886 (2002).

200 Id.

201 See generally Kalman Applbaum, Pharmaceutical Marketing and the Invention of the Medical Consumer, 3 PLOS MED. E189 (2006), $\mathrm{http}: / / \mathrm{www}$. plosmedicine.org/article/fetchObject.action?uri=info\%3Adoi\% 2F10.1371\%2Fjournal.pmed.0030189\&representation=PDF, archived at http://perma.cc/ZGB7-Y48M; Moynihan \& Henry, supra note 197. 
risk of the proposed product, overestimates value to the individual, changes how consumers frame their problems, and shifts how they see the range of potential answers. ${ }^{202}$ Pointing out to the consumer what has happened and providing alternative sources of information are successful ways of responding to these common areas of misperception and can improve decision making substantially. ${ }^{203}$

The risks to consumers posed by these products range from obvious physical injury by ingesting novel substances or applying electrical current to the brain, to the more subtle loss of opportunity harms (i.e. diversion of time and resources from activities that are more likely to be beneficial to the consumer). Although the weighing of cost and benefit and safety and efficacy belongs to the consumer using these self-improvement products, when claims of brain manipulation are made, there are additional concerns about efficacy and reliability of the information and product.

\section{B. Examples of Information Offered to Consumers}

In the section that follows, brain self-help technology websites were reviewed and quotations have been excerpted to demonstrate the information that consumers are often faced with when searching for and making decisions about brain self-help products.

A popular website 204 lists many untested or unproven self-improvement modalities for brain health and cognitive enhancement clothed in the language of health and science, including books and tapes, supplements, cranial electrical stimulation ("CES") devices, light and sound machines, home EEG and biofeedback devices, and colloidal silver generators that will enable the consumer to "take control of

202 See Jon D. Hanson \& Douglas A. Kysar, Taking Behavioralism Seriously: Some Evidence of Market Manipulation, 112 HARV. L. REV. 1420 (2008); See generally UBEL, supra note 181.

203 Annie Y.S. Lau \& Enrico W. Coiera, Can Cognitive Biases during Consumer Health Information Searches Be Reduced to Improve Decision Making? 16 J. AM. MED. INFORMATICS ASS'N 54 (2009); see also SUNSTEIN \& THALER, supra note 181.

204 ELIXA PEAK BEING, http://elixa.com (last visited Apr. 7, 2014). 
your physical and mental health."205 The website material reflected an overt attempt to facilitate consumer trust in the products by attempting to ground them in science, indicating that the company "has evolved as the result of over 30 years of research." The supplier further claimed that products were "personally tested and researched" 206 implying both safety and efficacy. And most directly the advertising suggested that the consumer "will find products that go beyond simple maintenance and quick 'cures,"'207 implying a categorical separation between the listed products and all others.

Under the cranial electrical stimulation category, the website proclaims, "Stress is our nation's \#1 health problem. It is the source of the anxiety, depression, and insomnia plaguing millions of Americans. Stress accounts for more than two-thirds of family doctor visits and is an important risk factor in all major illnesses. Left unchecked, it is a killer." 208 These are examples of enhancing frequency statistics, pathologizing common and poorly described mental states, and catastrophizing a lack of attention to the identified common severe impairment.

Although the disclaimer language later indicates that these are not health claims, the remainder of messages on the website clearly surround brain manipulation. Unlike the product marketing language expressed in plain language, placed in the center of the page and in large attractive font, the terms of use are located in a rather inconspicuous place on the website and are introduced as follows: "Please read the legalese about the limits of our liability and your responsibility for using experimental healing modalities." 209 The term legalese is defined by Miriam Webster dictionary as "the language used by lawyers that is difficult for most people to understand" and

$\begin{array}{ll}205 & I d . \\ 206 & I d \\ 207 & I d . \\ 208 & I d . \\ 209 & I d .\end{array}$


"specialized language of the legal profession."210 The very use of this word seems to indicate that the advertiser specifically made the information obtuse. This designation of the language as difficult or foreign to the consumer tends to separate the consumer from the very systems seeking to protect him or her and is in distinct contrast to the consumer-friendly language about the product. The placement and use of language both appear to be obvious attempts to dissuade the consumer from reading and considering the material. This is an example of a framing effect.

The disclosures then explicitly paint the product information offered as educational and recreational,

The information provided by ELIXA.COM is for educational and entertainment purposes only and should not be interpreted as a recommendation for a specific treatment plan, product, or course of action. ELIXA.COM does not provide specific medical advice, and is not engaged in providing medical or professional services. Use of ELIXA.COM does not replace medical consultations with a qualified health or medical professional to meet the health and medical needs of yourself or a loved one. ${ }^{211}$

The concept that this is education and entertainment should be rejected out of hand as patently disingenuous given the remainder of the material contained in the website. Examples of specific health claims include "Cranial Electrical Stimulation for mood, IQ, addictions."212 Specifically, the CES Ultra advertisings indicated that it

210 Legalese Definition, MERRIAM-WEBSTER, http://www.merriamwebster.com/dictionary/legalese (last visited Apr. 7, 2014), archived at http://perma.cc/6WQC-8L22.

211 Terms of Use, ELIXA PEAK BEING, http://elixa.com/terms.htm (last visited Apr. 7, 2014), archived at http://perma.cc/CH4Z-DW73.

212 Mind Machines, ELIXA PEAK BEING, http://www.elixa.com/mental/mental.htm (last visited Apr. 16, 2014), archived at http://perma.cc/AT3Y-RYSL. 
would enhance cognition and memory, elevate mood, and stabilize sleep. The mind machine is a bit more suggestive, orienting the consumer with the statement, "Our Mind Machines will make you smarter, more productive, happier, relaxed, and in the zone." 213 The website then offers this quotation from a book that demonstrates suggestion, framing, promise of biological change, subjective criteria for measuring improvement, and reference to increasing numbers of people using the technology:

You sit down comfortably, don the electrical headgear, flip a switch, close your eyes and sink into a state of what seems like deep relaxation. A half hour later, as you turn off the machine, you feel extremely alert and lucid.

Your brain is now functioning more effectively than it was before. Your memory -- both your ability to memorize new information and to recall information you have already learned -has increased dramatically. Your ability to think creatively, to solve problems, has expanded. The speed with which your brain cells pass messages among themselves has increased. In fact, many of your brain cells have actually grown a microscopic examination would show that the brain cells have developed more dendrites, the branching filaments that carry messages from one cell to another, and more synapses, the junctures between the brain cells across which impulses are transmitted. You are more intelligent than you were a half hour before.

Such devices now exist and are being used by increasing numbers of people..$^{214}$

213 Products and Protocols for Peak Performance, ELIXA PEAK BEING, http://www.elixa.com/index.html (last visited Apr. 16, 2014), archived at http://perma.cc/S2XT·RTS4.

214 Id. 
The terms of service go on to explain that the website management "does not and cannot review all communications posted to ELIXA.COM,"215 explaining that it contains links for the convenience of the reader without any implication of endorsement, operation, or control of the third party business. Although the website touts the health benefits of products, it does not contain warning letters or critiques of its products, including the ingestion of colloidal silver allegedly made from generators. ${ }^{216}$ In fact, it goes so far as to say why argyria (skin turning blue due to silver ingestion) will not occur. ${ }^{217}$ Other undisclosed harms of silver ingestion include kidney damage and neurological problems such as seizures. The FDA published position excerpted below is unlikely to come to the attention of the average consumer using this website as it is absent from the product website and not prominent in any consumer forum:

Silver is present in the environment, and
therefore people are normally exposed to it.
However, silver is a nonessential mineral that
has no known physiological functions or
benefits when taken orally.

Silver has some appropriate medical uses, such as medicines, bandages, and dressings used to treat burns, skin wounds, or skin infections, and as medicines used to prevent the eye condition called conjunctivitis in newborn infants. However, there are no legally marketed prescription or over-the-

$215 I d$.

216 See, e.g., Consumer Advisory: Dietary Supplements Containing Silver May Cause Permanent Discoloration of Skin and Mucous Membranes (Argyria), U.S. FOOD AND DRUG ADMINISTRATION (Oct. 6, 2009), http://www.fda.gov/food/recallsoutbreaksemergencies/ safetyalertsadvisories/ucm 184087.htm, archived at http://perma.cc/ A9XB-HQXW.

217 Make Your Own Colloidal Silver, the Antibiotic of the Future!, ELIXA PEAK BEING, http://www.elixa.com/silver/index.html (last visited Apr. 8, 2014), archived at http://perma.cc/HF5D-2PPK. 
counter (OTC) drugs containing silver that are taken by mouth.

FDA regulates dietary supplements under a different set of standards than those that apply to drugs. For example, FDA does not approve dietary supplements or their labels before they are sold. It is unlawful for a manufacturer to represent a dietary supplement containing silver as able to prevent, diagnose, mitigate, treat, or cure any disease. ${ }^{218}$

In this example, the alleged health benefits were described over many pages, disclosures were not present, and adverse effects were not mentioned anywhere. Regardless of the status of product purveyors as health providers, the disclosure of risk in the face of claimed benefit is a responsibility the marketer bears with regard to the consumer.

In addition to disingenuous and incomplete content, negative framing language, and inconspicuous placement, these disclosures are also frequently presented to consumers in ways that make them unlikely to be noticed or read by the consumer. The disclosure in Figure 1 features small font, poor resolution, inconspicuous location, and a message that is inconsistent with the rest of the site. These qualities make the information less likely to be viewed by the consumer. ${ }^{219}$

Again, the disclaimer says that the suppliers are not health practitioners and information comes from a variety of sources, this website describes doing things to the body to

218 Consumer Advisory, supra note 214; see also Over-the-Counter Drug Products Containing Colloidal Silver Ingredients or Silver Salts, 64 Fed. Reg. 44,653, 44654 (Aug. 17, 1999).

219 See generally, e.g., Dan J. Graham \& Robert W. Jeffery, Location, Location, Location: Eye-Tracking Evidence that Consumers Preferentially Positioned Nutrition Information, 111 J. AM. DIETETIC Ass'N 1704 (2011). 
achieve a health outcome (i.e. putting electrodes on the wrists to cleanse the blood from viruses and toxins, magnetizing lymphatics, and drinking colloidal silver and freshly ozonated water to optimize benefits received from the Brain (now called Bio) Tuner and light therapy). ${ }^{220}$

Figure 1.

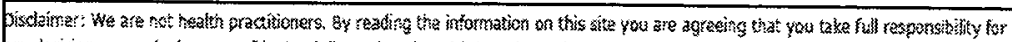

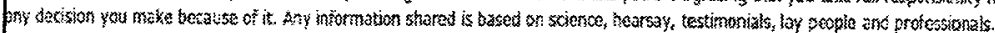

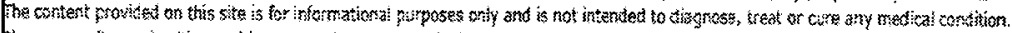

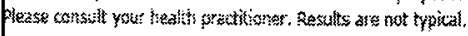

A Canadian retailer of a device goes on to add a disclaimer specific to the sale of the device (see Figure 2).221 This particular disclosure goes on to define the site of the transaction as in Canada, presumably an additional strategy to avoid potential action by U.S. regulatory authorities.

Figure 2.

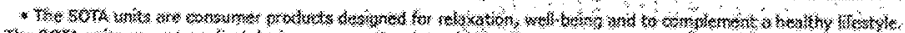

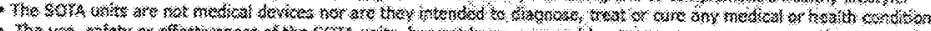

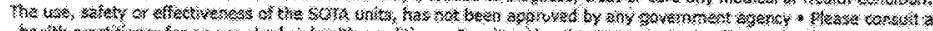

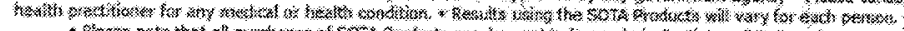
- Fo

Another website goes on to say that addiction, insomnia, and anhedonia are the result of brain problems that the Bio Tuner corrects. ${ }^{222}$

Alleged brain stimulators and colloidal silver generators are not alone in this parsing of the line between education, recreation and health care. The following "information" is provided to consumers to assist them in understanding light therapy.

220 What is the Beck Protocol?, SHARING HEALTH, http://www.sharinghealth.com/bob-beck-protocol.html (last visited Apr. 8, 2014), archived at http://perma.cc/DKX8-2QL7.

221 Our Products, SoTA, http://www.sota.com/sota-products.html (last visited Apr. 8, 2014), archived at http://perma.cc/47NS-P8A8.

222 Balancing the Brain, SHARING HEALTH, http://www.sharinghealth.com/bob-beck-brain-tuner.html (last visited Apr. 8, 2014), archived at http://perma.cc/B9TW-EEDX. 
Mode E, 4,672 Hz - Nerves

Used for spinal and skin disorders. Resonates with the spinal cord and peripheral nervous system. Also considered helpful for pain control. ...

\section{Mode F, $73 \mathrm{~Hz}$ - Emotional Reactions}

Resonates with the subcortical or lower regions of the brain. Includes the thalamus and hypothalamus - two major control centers for body functions. May also help with muscle spasms, facial pain, headaches and depression. Has been used for non-healing bone fractures. May also help to balance hormones.

\section{Mode G, $146 \mathrm{~Hz}$ - Intellectual Organization Used for memory and psychological disorders. Resonates with the cerebral cortex of the brain-involved with thinking, imagining and creating. May help with nervousness and worry. ${ }^{223}$}

Another brain self-help website has a more extensive, but no more informative, disclaimer. In the example below, the author of the disclaimer acknowledges that experts might disagree, disavows responsibility for the informational content of the site, rejects the implication of warranty and directs the reader to a provider. Yet, none of the products on the website require a prescription from the consumer's local healthcare provider.

Altered States products are sold for learning, self-improvement and simple relaxation. No statement contained in this catalogue, and no information provided by any Altered States employee, should be construed as a claim or 
representation that these products are intended for use in the diagnosis, cure, mitigation, treatment or prevention of disease or any other medical condition. The information contained in this catalogue is deemed to be based on reliable and authoritative report. However, certain persons considered experts may disagree with one or more of the statements contained here. Altered States assumes no liability or risk involved in the use of the products described here. We make no warranty, expressed or implied, other than that the material conforms to applicable standard specifications.

The publisher does not accept any responsibility for the accuracy of the information or the consequences arising from the application, use, or misuse of any of the information contained herein, including any injury and/or damage to any person or property as a matter of product liability, negligence, or otherwise. No warranty, expressed or implied, is made in regard to the contents of this material. No claims or endorsements are made for any drugs or compounds currently marketed or in investigative use. This material is not intended as a guide to self-medication. The reader is advised to discuss the information provided here with a doctor, pharmacist, nurse, or other authorized healthcare practitioner and to check product information (including package inserts) regarding dosage, precautions, warnings, interactions, and contraindications before administering any 
drug, herb, radionics tool, or supplement discussed herein. ${ }^{224}$

The above disclaimer appeared in the context of more than eleven printed pages on the treatment of drug withdrawal, pain, depression, anxiety, and memory deficits on a website selling products ranging in price from approximately $\$ 30$ to over $\$ 1000$.

While these product claims, when combined with the disclosures, may meet some minimal regulatory standard, they are not effective consumer information and do little to correct the informational asymmetry between the consumer, actual state of the science, and claims of the manufacturer or marketer.

\section{Enhancing Consumer Literacy}

Although product information, disclaimers, labels, and instructions are considered by many to be among the most important sources of consumer education, the reality is that this product information is often difficult to understand owing to the brevity of the information provided, lack of contextual data, complex names, and terms and large amount of distracting general information. These features may cause consumers to overlook this information. There are also varying rules and regulations that detail how much information needs to be provided so that the idea of complete disclosure is more myth than reality.

In addition to product information provided directly to the individual consumer, consumer watch groups have a role to play in informing and empowering consumers by providing credible information and reviews. Since trust is a prominent factor in both interpretation of the science and in product selection, third party consumer watch groups may have a strong role to play in improving knowledge and therefore more advantageous product selection by consumers. The National Consumers League is a private

224 ALTERED STATES, http://altered-state.com/index2.htm (last visited Apr. 8, 2014), archived at http://perma.cc/T87P-6DDK. 
non-profit advocacy group with a consumer website, ${ }^{225}$ but it does not appear to list many brain self-improvement products in a searchable fashion. Quackwatch.com, on the other hand, is a website that reviews products and claims in a more easily searchable fashion. It provides lists of reliable and unreliable sources of health information and is equally critical of private and governmental ventures that it considers suspect. Quackwatch is an international collaboration of experts closely affiliated with the National Council Against Health Fraud. ${ }^{226}$

While there are a number of government consumer information sites such as those through the Department of Health and Human Services'227 Centers for Disease Control and Prevention and the National Health Information Center, 228 the information is not arranged in a way conducive to consumer access. Regarding brain health and product information, Consumer Health and Human Services Information and Resources and the Consumer Information Center are no better. ${ }^{229}$ Similarly, the National Institutes of Health offer information sites and bibliographies that could potentially be of use to consumers but are difficult to navigate, often fail to speak to specific brands of products and point to references that are not accessible to the average consumer. Consequently, some of

225 NATIONAL CONSUMERS LEAGUE, http://www.nclnet.org (last visited Apr. 8, 2014), archived at http://perma.cc/66AG-8QE5.

226 QUACKWATCH, http://www.quackwatch.org (last updated Mar. 23, 2014), archived at http://perma.cc/ZC2Z-N8QS.

227 HEALTHFINDER.gOV, healthfinder.gov (last updated Apr. 8, 2014), archived at http://perma.cc/5HY4-6CQH.

228 "The National Health Information Center (NHIC) is a health information referral service. NHIC links people to organizations that provide reliable health information. NHIC was established in 1979 by the Office of Disease Prevention and Health Promotion (ODPHP), Office of Public Health and Science, Office of the Secretary, U.S. Department of Health and Human Services." National Health Information Center, HEALTH.GOV, http://www.health.gov/nhic/ (last updated Apr. 8, 2014), archived at http://perma.cc/KT2C-7JUZ.

229 See generally

PUBLICATIONS.USA.GOV, http://publications.usa.gov (last visited Apr. 8, 2014), archived at http://perma.cc/PN2G-HXPP. 
the agencies likely to engender the highest levels of consumer trust also pass the highest information costs on to consumers by devising information sources that are not particularly user friendly.

Even when information is available, increasing scientific and health literacy will be one important step in helping the consumer become savvier regarding brain products. While compulsory public education is a good start, many advances will occur following the consumer's exit from formal education, and students frequently leave school without the skills necessary to understand these advances. At present, functional neuroimaging does allow researchers and clinicians to peer inside the skull and observe the living human's brain activity. However, the massive amounts of data produced are interpreted and reduced to pictures using complex statistical methods that are based on both a variety of assumptions and the nature of the research question asked. There is nothing simple or straightforward about experimental design, imaging modality or data interpretation in this field, and to suggest otherwise is, at best, foolhardy and, at worst, fraudulent.

In building scientific literacy, scientific reporting will need to be more thorough and include disclosures when appropriate. In addition to identifying the limitations of the technology generally, there are study-specific issues of which consumers should be made aware including small sample size, uncontrolled multiple comparisons, overinterpretation of the data, findings of uncertain significance, and indications of premature or biased reporting. As consumers become aware of these factors it will become more difficult for commercial entities to leverage the brain image and the rhetorical brain construct to induce certainty about things in which there is none. As scientific literacy improves, individuals may also more accurately assess privacy concerns related to neuroimaging databases by being better able to differentiate valid versus 
faulty inferences about internal mental states derived from brain images. 230

With improvements in consumer understanding of the technologies and studies and advances in the technologies themselves, communications to consumers via the media or regulation may begin to shift from a threshold kind of communication (i.e. whether a product could actually do what it purports) to more nuanced conceptualizations of risk-benefit and cost-value analyses. Many information websites that might rightfully garner consumer trust are simply not user-friendly. They are not keyed to find the terms consumers search for, are difficult to navigate, and are frequently not engaging in their presentation. Product placements in commercial websites are, in fact, engaging, accessible, and persuasive. While there are on-going attempts to make balanced consumer education more engaging, this work is in its relative infancy and only likely to be of benefit to future consumers.

Accepting that consumers consider most brain and brain product stories and advertisements to be health information at some level, is there a role for traditional healthcare systems in enhancing consumer literacy? Most of the people who used the internet to search for health information also "got information, care, or support from a doctor or other healthcare professional," 231 indicating that there is an opportunity for the traditional health system to provide information about the brain and brain products to the consumer. Some have pointed to the provider-patient relationship as "a reservoir of solutions to the challenges created by unproven interventions and translational research." 232 Yet, there is a move in healthcare to decrease reliance on routine health checks by physicians and other

230 See Rachul \& Zarzeczny, supra note 99, at 77-81.

231 Susannah Fox \& Maeve Duggan, Pew Research Ctr., Health ONLINE 2013 (2013), available at http://www.pewinternet.org/ /media// Files/Reports/PIP_HealthOnline.pdf, archived at http://perma.ccl 4WWA-B38G.

232 Eric Racine et al., Proven or Unproven? Panel Report on Ethics in the Translation of Neuroscience. 39 CAN. J. NEUROLOGICAL SCI. 247, 249 (2012). 
healthcare providers. Both the annual wellness physical examination and the ordering of laboratory assessment in the asymptomatic patient have been found to lack cost effectiveness. ${ }^{233}$ Most healthcare providers will therefore be dealing with individuals who are already ill, not the rational well consumer seeking self-help.

The involvement of physicians and other healthcare providers in the supervision or provision of alternative medicine technologies has been a topic of concern for individuals and healthcare entities, although historically recommendations or referrals for self-improvement activities, supplements and devices have not been a prominent source of practitioner liability exposure. ${ }^{234}$ Many brain self-improvement products are authored or endorsed by one or more entities with alleged expertise or authority (many advertising themselves as medical doctors, alternative practitioners or doctors of philosophy). Physicians and other practitioners may also write blogs, offer advice online and write prescriptions for devices or medications purchased by patients online who may not wish to visit a terrestrial provider. Liability issues related to these activities are unclear. ${ }^{235}$

As interactions between healthy adults and care professionals decrease, and professionals enter the world of general self-improvement outside interactions with

233 HANNA E. BLOOMFIELd ET AL., VA-ESP PROJECT \#09-009, Evidence BRIEF: ROLE OF THE ANNUAL COMPREHENSIVE PHYSICAL EXAMINATION IN THE AsYMPTOMATIC ADULT (2011); Stephanie Thompson \& Marcello Tonelli, General Health Checks in Adults for Reducing Morbidity and Mortality from Disease, THE COCHRANE LIBRARY (Oct. 9, 2012), http://www.thecochranelibrary.com/details/editorial/2723031/ General-health-checks-in-adults-for-reducing-morbidity-and-mortalityfrom-diseas.html, archived at http://perma.cc/58QF-5QXR.

234 See generally Mark S. Salzer \& Loran B. Kundra, Liability Issues Associated with Referrals to Self-Help Groups, 61 L. \& PSYCHIATRY 6 (2010); C. Lee Ventola, Current Issues Regarding Complementary and Alternative Medicine (CAM) in the United States, 35 P\&T 570 (2010); Joan Gilmour et al., Hospitals and Complementary and Alternative Medicine: Managing Responsibilities, Risk, and Potential Liability, 128 PEDIATRICs S193 (Supp. 2011).

235 See Terry, supra note 30. 
individual patients, it would seem that strong normative stands by professional organizations and clear communications to consumers about these technologies are necessary parts of a consumer-centric education effort. Yet, no consumer-oriented statements by professional organizations in the area of neuro self-improvement could be located.

With few exceptions, scientific groups and organizations have been relatively uninvolved in correcting public perception 236 and limiting commercial brain self-help technologies. Some observers, in fact, blame both clinicians and scientists for shirking their responsibilities to the public by allowing their findings to be skewed in the popular media. A notable exception is an expert consensus panel that recommended consumers (1) look for products that can substantiate the claims made with independent verification, (2) separate items founded on plausible reasoning from those that have actually been tested, (3) not mistake improvement in a concrete task with global cognitive improvement, (4) consider that short-term improvement may not translate into long-term improvements, and (5) consider traditional activities that also result in cognitive improvement such as, for example, physical exercise, socializing with others, or learning a new life skill. ${ }^{237}$ Though it is not popularized, this panel report is a promising attempt to provide direct actionable information to consumers.

\section{MeChanisms of CONSUMER PROTECTION}

Brain self-help products seem to have been able to have it both ways; that is, "inform" consumers that these are

236 Wardlaw et al., supra note 42; Sharon Morein-Zamir \& Barbara J. Sahakian, Neuroethics and Public Engagement Training Needed for Neuroscientists, 4 TRENDS CoGNITIVE SCI. 49 (2010).

237 Expert Consensus Statement on Brain Health, STAN. CTR. ON LONGEVTTY, http://longevity3.stanford.edu/brain-health/expertconsensus-on-brain-health/ (last visited Apr. 8, 2014), archived at http://perma.cc/5DH5-U28J. 
powerful products with the ability to change their brains yet escape the formal regulation accompanying traditional diagnostic and therapeutic modalities making similar claims. These products seem to put forth claims that they change physical brain activity without having to disclose that everything a person does changes brain activity and without any particular demonstration of concept. ${ }^{238}$ Sometimes these products are based on a shred of truth, or novel application of plausible biological principles, but at other times they seem based on neuromyth or sheer fantasy. The inability (or unwillingness) of commercial interests, consumer watch groups, and science watch groups to provide accessible information to consumers on which they could differentiate valid, potentially valid, and unlikely valid claims may be conceptualized as a market failure. As one observer noted, "When markets don't provide consumers with the information they need to make good decisions, the markets have failed, and policy makers need to take steps to make sure consumers get such information."239

If the use of these self-help products is considered a hobby or recreational pastime, then the risk disclosure alone would be adequate, and further use would presumably be driven by the pleasure derived from its use. Although it would be convenient for industry to conceptualize that these technologies are recreational, available evidence suggests that brain self-help advertisements make health claims and consumers turn to these technologies for health-related concerns, so it is reasonable to conceptualize these health products falling under the FDA and FTC regulatory authority.

When costs and risks are relatively low, these products might seem harmless and mistakes in using them could be subsumed under a kind of consumer naiveté that will

238 See generally KATHLEEN TAYLOR, THE BRAIN SUPREMACY: NoTES FROM THE FRONTIERS OF NEUROSCIENCE (2012); TALlis, supra note 3; Should Neuro-Products be Regulated Like Pharmaceuticals?, NEUROBOLLOCKS (May 23, 2013), neurobollocks.wordpress.com/ category/brain-training, archived at http://perma.cc/6ZUM-VZ7K.

239 UBEL, supra note 181 , at 14. 
benefit from one trial of falling for an ineffective claim. However, this assumes a healthy, and well-informed, consumer acting on his or her own behalf, and that it is not uniformly the consumer that seeks and uses online health information such as that put forward in brain self-help. Additionally, the advertisements tend to appeal to parents to use these products on their children and to individuals at risk for cognitive decline, so the well, young-adult consumer acting to fine tune his or her own body is only a portion of the market.

Brain-themed self-improvement materials such as books, recordings, games and apps would generally fall into the category of low-risk and-low cost endeavors that seem to attract a minimum of regulatory attention. When considering foods, supplements and devices for brain health and manipulation, public and private regulation becomes more complex with substantive regulation dealing with basic safety data and claims made. In situations in which physical risk remains relatively low, these more complex regulations provide a more minimal safety net than consumers assume and are perhaps no more useful to consumers than labels and disclaimers.

\section{A. Self-Regulation and Soft Law}

In an ideal world, self-regulation would rule the day. ${ }^{240}$ The arguments for self-regulation center around the idea that involvement in the enterprise is voluntary and that it is good business for producers to do adequate research before developing a product to make certain that it is effective, to produce a quality product, and then to stand behind that product, else risk losing market share. ${ }^{241}$

240 See Robert Pitofsky, Self Regulation and Antitrust, FED. TRADE COMM'N (Feb. 18, 1998), http://www.ftc.gov/news-events/pressreleases/1998/02/self-regulation-and-antitrust, archived

at http://perma.cc/E97Z-2H33; ADAM SMITH, WEALTH OF NATIONS, 1909-14 (C. J. Bullock, ed., New York, P.F. Collier \& Son 2001), available at www.bartleby.com/10/. 
Additionally, self-regulation is nimble and prompt in responding to problems experienced in the marketplace. ${ }^{242}$ Proponents will go on to argue that common law mechanisms exist for fraud and injury, and that those should be sufficient for consumer protection. Voluntary self-regulation is pitched as cost-effective and good for everyone. ${ }^{243}$ Corporate codes of conduct and internal reviews are examples of self-regulation at the level of the single business. ${ }^{244}$ An example of self-regulation in a larger corporate ecosystem is the Advertising Self-Regulatory Council administered by the Council of Better Business Bureaus. ${ }^{245}$

In addition to internal self-regulation, companies may also voluntarily submit their products to private groups for review by agents external to the company. Underwriters Laboratories is one such company. It was established in $1894,{ }^{246}$ to ensure safety of devices, but does not assess the validity of claims made by the device. For example, some consumer cranial electrical stimulation devices carry the following designation: "Medical Electrical Equipment classified by Underwriters Laboratories Inc. ${ }^{\circledR}$ with respect to electric shock, fire, mechanical and other specified hazards only in accordance with UL-2601-1 and CAN/CSA C22.2 No. 601.1. 34VF."247 The Underwriters Laboratories approval carries weight with consumers as a signal of overall product safety and quality despite the fact that this

242 Id.

243 Pamela Jones Harbour, Fed. Trade Comm'r, Helping the FTC HelP You: EFFECTIVE SElf-REgulation IS BetTeR Business (2005).

244 See Virginia Haufler, A Public Role for the Private Sector 7-30 (2001).

245 See Supporting Advertising Industry Self-Regulation, ASRC, http://www.asrcreviews.org/supporting-advertising-industry-self-regulation/ (last visited Apr. 8, 2014), archived at http://perma.cc/YAC-2LXN.

246 See generally UNDERWRITERS LABS., http://www.ul.com (last visited Apr. 8, 2014), archived at http://perma.cc/38KQ-8QD4.

247 OWNER'S MANUAL, ALPHA-STIM SCS (2002), http://biomedical.com/media/support/alpha-stim-scs-user-manual.pdf, archived at http://perma.cc/8Z98-VNK3. 
approval only pertains to physical risk and not to claims made.

\section{B. Direct Regulation}

Informed and useful regulation must balance consumer desires for new information and products with product safety and reasonable controls on claims made. Command and control regulation may have an advantage over selfregulation in including multiple points of view, not relying on volunteerism, and having the ability to impose sanctions and demand withdrawal of the product or the claim from the marketplace. ${ }^{248}$ Of course, opponents claim that command and control mechanisms risk slowing innovation, while proponents claim that these types of protections are essential for the protection of the public.

While far from the only regulatory mechanisms applicable to brain self-improvement products, ${ }^{249}$ the two command and control mechanisms that will be considered here are the FTC and FDA.

The FTC, 250 via its Bureau of Consumer Protection, is tasked with the prevention of fraud, deception, unfair business practices, and provision of free consumer information. ${ }^{251}$ The FTC covers advertising of over the counter medications, foods and devices. Section 45 of the Federal Trade Commission Act gives the FTC power to

248 Pitofsky, supra note 240.

249 For example, state product safety legislation and policy are in place. Glenn Kaplan \& Chris B. Smith, Patching the Holes in the Consumer Product Safety Net: Using State Unfair Practices Laws to Make Handguns and Other Consumer Goods Safer, 17 YALE J. ON REG. 253 (2000).

250 The FTC is comprised of seven divisions including advertising practices, consumer and business education, enforcement, financial practices, marketing practices, planning and information, and privacy and identity protection. About the Bureau of Consumer Protection, FED. TRADE COMM'N, http://www.ftc.gov/bcp/about.shtm (last visited Apr. 8, 2014), archived at http://perma.cc/L7N-QYAX.

251 See Consumer Information, FED. TRADE COMM'N, http://www.consumer.ftc.gov (last visited Apr. 8, 2014), archived at http://perma.cc/S8W9-XCLK. 
investigate unfair and deceptive acts or practices including the omission of information material to a consumer's choice. 252 Upon a finding of unfair or deceptive practices, the FTC may issue a cease and desist order and leverage penalties for violations, ${ }^{253}$ such as when Kellogg advertised that Mini-Wheats improve attention. ${ }^{254}$

The FDA regulates the advertising of prescription drugs and restricted devices and handles misbranding and labeling issues. ${ }^{255}$ In drugs and restricted devices, products regulated are those products intended to diagnose, cure, prevent or treat disease or intended to affect the structure or function of the body. ${ }^{256}$ Where printed materials or websites make certain health claims, the FDA may become involved, most commonly issuing warning letters. ${ }^{257}$

The FDA also regulates health claims made by foods and supplements. A health claim occurs when there is a stated relationship between the food or supplement, or a component, and reduced risk of a disease or health condition. Although the term "functional" is sometimes foods and dietary ingredients making health claims beyond general nutrition, the term has no legal definition and is not under a separate regulatory scheme. The FDA, instead, regulates these products using the existing food regulatory scheme consisting of foods (conventional, modified or medical), food additives and dietary supplements, a system

25215 U.S.C. $\$ 45$ (2014).

253 Id.

254 Press Release, Fed. Trade Comm'n, Kellogg Settles FTC Charges That Ads for Frosted Mini-Wheats Were False (Apr. 20, 2009), available at http://www.ftc.gov/news-events/press-releases/2009/04/ kellogg-settles-ftc-charges-ads-frosted-mini-wheats-were-false, archived at http://perma.cc/DK3P-K7L2.

255 What Does FDA Regulate, U.S. FOOD AND DRUG ADMINISTRATION, http://www.fda.gov/AboutFDA/Transparency/Basics/ ucm 194879.htm (last visited Nov. 19, 2013), archived at http://perma.cc/7NWF-L67Z.

25621 U.S.C. $\$ 321(\mathrm{~g})-(\mathrm{h})(2014)$.

257 See generally Inspections, Compliance, Enforcement, and Criminal Investigations, U.S. FOOD AND DRUG ADMIN. (Mar. 22, 2011), http://www.fda.gov/ICECI/EnforcementActions/WarningLetters/2011/uc $\mathrm{m} 250701 . \mathrm{htm}$, archived at http://perma.cc/R92P-FGSQ. 
characterized by some as having arbitrary loopholes and inadequate enforcement strategies. ${ }^{258}$

More highly regulated would be devices that monitor or effect change in human physiology. 259 Devices such as home neurofeedback devices and "brain wave synchronizers" 260 might well fall under the jurisdiction of the FDA. However, as a natural consequence of the brain's rock star status, brain self-help products have grown in prominence, and regulation around claims made by individuals not directly involved in manufacturing and supplying products are unclear. ${ }^{261}$

\section{CES Devices: An Example of Regulation and Enforcement}

Cranial electrotherapy stimulation ("CES") devices use low intensity electrical stimulation, usually delivered through ear clips or electrodes in the head and neck area, to treat anxiety, depression, and insomnia. The devices are classified as experimental. Examining the challenge posed by these devices to regulatory systems may be instructive because it is an area in which the FDA has made significant attempts to curb excessive claims and examine the risk benefit analysis. ${ }^{262}$

258 David Kaplan, Ethics and the Life Sciences, 32 J. PHIL. RES. 177 (2007).

259 Recently, the FDA issued guidance on apps. See generally BRADLey MERRILl THOMPSON, FDA REgulation OF MOBILE Health OCTOBER (2013). This work provides an overview of FDA regulation for innovators.

260 Stephen Barrett, Questionable "Self-Help" Products, QUACKWATCH, http://www.quackwatch.com/01QuackeryRelatedTopics/ mentprod.html (last updated Aug. 18, 2004), archived at http://perma.cc/Q8TX-8VPE.

261 See Kyle Sampson \& Kayte Spector-Bagdady, Administrative Law \& Regulation: The Regulation of Prescription Drug and Restricted Medical Device Advertising, 11 ENGAGE 4 (2010).

262 FoOD \& DRUG ADMINISTRATION, PETITIONS to Request Change IN CLASSIFICATION FOR CRANIAL ELECTROTHERAPY STIMULATORS (2012), available at $\mathrm{http}: / / \mathrm{www}$.fda.gov/downloads/AdvisoryCommittees/ CommitteesMeetingMaterials/MedicalDevices/MedicalDevicesAdvisoryCo 
Though this kind of therapy likely has its origins in studies conducted in the eighteenth century, efficacy has yet to be established in adequately powered controlled clinical trials. This example is particularly relevant because many observers predict that the next wave of treatments for biobehavioral disorders will be in the area of neuromodulation, and, thus, the consumer will be faced with hearing about the likely successes of clinical neuromodulation and having to figure out whether consumer level devices are sufficiently similar to clinically available ones to be of use or are sufficiently different and to be avoided.

In the late 1970s, the FDA placed these devices in Class III owing to the lack of convincing data demonstrating benefit. The placement in Class III triggers the FDA's most stringent application process for premarket approval ("PMA") of devices. In 1997, the PMA requirement was revoked, and the FDA considered a move to Class I or II, inviting device manufacturers to submit evidence of safety and efficacy.

In 2009, the FDA obtained additional information from manufacturers and in 2011 published a proposed rule to again require premarket approval for CES devices. In 2012, the FDA's Neurological Devices Panel met and came to the decision and concluded that Class III placement with a PMA requirement was appropriate. During the time in which these devices could enter the market without PMA, device suppliers entered the market making claims that devices were FDA approved or cleared for the advertised purposes that usually extended well beyond the three indications for which the device had actually been cleared. One CES device manufacturer in particular has been vocal about FDA action requiring premarket approval for claims made. It initially claimed that the product was FDAapproved for a number of indications. The labeling was then changed to indicate it was FDA-regulated. When the FDA reinstated the PMA requirement, the manufacturer

mmittee/NeurologicalDevicesPanel/UCM290787.pdf, archived $a t$ http://perma.cc/VJ9R-B26T. 
then went on the offensive claiming that the FDA was stalling the process and depriving consumers of technologies that the government itself is using. ${ }^{263}$

EPI's largest customer is currently the United States government, and preventing the marketing of Alpha-Stim $®$ would deprive our Soldiers and Veterans of an effective tool in their battle against insomnia, anxiety, depression and PTSD. Ironically, while one branch of government (FDA) is attempting to justify spending millions of dollars to prevent the marketing of CES, other branches (the DOD and VA) are spending millions of dollars purchasing Alpha-Stim $\otimes$ CES and on research to study the effects of Alpha-Stim ${ }^{\circledR}$ CES on our Soldiers and Veterans. ${ }^{264}$

The document ends with a call to action "EPI is asking that you simply tell FDA the truth about how safe and effective CES is for you and/or your patients. EPI will deal directly with the issues in the Proposed Rule."265 EPI also refers to itself as the most regulated company in the United States and has links to alleged improper behavior by the FDA.

In the midst of these machinations, it is not at all clear that consumers understand the differences between terms like FDA-approved, -cleared, -regulated, and -allowed, so the supplier of the technology is able to sustain the appearance of governmental testing of efficacy when, in fact, the product may be regulated due to a lack of efficacy

263 See generally ALPHA-STIM, PETITIONER PRESENTATION TO NEuRologicAl DeVICES PANEL FOR REClASSIFICATION OF ALPHA-STIMß CES DEVICES FROM CLASS III TO ClASS II (2012), available at http://www.alpha-stim.com/wp-content/uploads/EPIs-fda-presentation.pdf, archived at http://perma.cc/RP7Z-M5MY.

264 ALPHA-STIM, EPI FACT SHEET, available at http://www.alphastim.com/wp-content/uploads/EPI-Fact-Sheet.pdf, archived at http://perma.cc/7H37-NS7W.

265 Id. 
combined with an unacceptable risk of side effect. ${ }^{266}$ While technically true, this is misleading: "CES in the United States has received Food and Drug Administration marketing clearance for the treatment of anxiety, depression, and insomnia. CES devices are sold over the counter in Europe and other parts of the world."267 Again, this is an example of appealing to potential consumer biases by framing the technology as safe and effective and suggesting that the rest of the world uses it without government interference.

It is not difficult to conceptualize potentially informative text about these issues. Consider these two examples: "FDA believes that the available scientific evidence supports a Class III determination because the data do not support a reasonable assurance of safety and effectiveness, the proposed special controls would be insufficient to provide such assurance, and there is an unreasonable risk of illness or injury," 268 or, even more simply phrased, "the suppliers of this device have not demonstrated effectiveness and safety so the FDA does not recommend, approve, or condone its use for any purpose."

The FDA has, in fact, made attempts to limit the claims made by Alpha-Stim, Health Directions, and others. ${ }^{269}$

266 See Patti Zettler, "Electroceutical" Ads Are Here. What Will Regulators Say, CTR. FOR LAW. Biosciences, STANFORd LaW SCH. (Oct. 24, 2013), http://blogs.law.stanford.edu/lawandbiosciences/2013/10/24/ electroceutical-ads-are-here-what-will-regulators-say/, archived at http://perma.cc/UAX9-NURC.

267 Alpha Theta Stim, ALTERED STATES, http://alteredstates.net/barry/newsletter203/alphathetastim.htm (last visited Apr. 8, 2014), archived at http://perma.cc/429U-S43G.

268 EPI FACT SHEET, supra note 264.

269 See, e.g., Warning Letter from Thomas D. Gardine, District Director, Philadelphia District, U.S. Food and Drug Admin., to Harold D. Stecker, President, Health Directions, Inc. (Mar. 4, 2004) [hereinafter Warning Letter to Harold D. Stecker], available at http://www.fda.gov/iceci/enforcementactions/warningletters/2004/ucm 14 6243.htm, archived at http://perma.cc/DV8P-JV7H; Warning Letter from Reynaldo R. Rodriguez, Jr., Dallas District Director, U.S. Food and Drug Admin., to Daniel L. Kirsch, Chairman, Electromedical Products Int'l, Inc. (Apr. 30, 2013) [hereinafter Warning Letter to Daniel L. 
However, on the most recent visit to the Alpha-Stim website this statement appeared: "Alpha-Stim is FDA Approved and can only be purchased with a prescription. To discuss your Alpha-Stim needs with Dr. James G. Friesen please call (818) 893-4463 and leave him a message."270 This clinical psychologist goes on to say, "Should you consider purchasing one, you will be pleased to know that AlphaStim is FDA approved and that no significant side effects have been reported in over two decades of use. The price is $\$ 795$, and that includes a five-year warranty." 271 He then says,

I believe it is unethical for therapists not to try using Alpha-Stim. Here is the point: If therapists know that something may help their patients and yet they refuse to try it, that is unethical. These are not simply "initial findings" - we have over [fifty] scientific studies that support these clinical observations. After continuing treatment with about [one hundred] people in therapy for over three years, I believe that my initial findings are supported by what my patients continue to report. Therapists are mandated to continue to learn about interventions that can help their patients, so if Alpha-Stim may help, therapists cannot afford to ignore that. ${ }^{272}$

The above text section also demonstrates the additional problems of professionals offering testimonials and making claims without apparent concern for action by regulatory authorities. By having an appointed practitioner offer

Kirsch], available at http://www.fda.gov/ICECI/EnforcementActions/ WarningLetters/2013/ucm351179.htm, archived at http://perma.ccl AH5Z-KJ4Q.

270 An Introduction to the Alpha-Stim Stress Control System, JAMESGFRIESON.COM, http://www.jamesgfriesen.com/alpha-stim.shtml (last visited Apr. 8, 2014), archived at http://perma.cc/V22E-EG8H.

271 Id.

$272 I d$. 
professional opinions and provide prescriptions, these companies work around any opportunity for consultative involvement by traditional healthcare outlets that could provide balanced and personalized information to the consumer.

While it might be reassuring from a physical safety perspective that the product price is clearly advertised, that it comes with a warranty and that it is not considered a shock risk, the ongoing marketing material suggesting that the device is FDA-approved, and the continued mentions of addiction and pain management, in addition to anxiety, depression and insomnia, are clearly inconsistent with the content of communications from the FDA.

Other suppliers market CES devices in a similar manner. Healthpax, for instance, markets the CES Ultra as enhancing "relaxed awareness, cognitive function, mental performance, memory and I.Q." Although it does not claim to be FDA-approved, Healthpax lists the device as having an FDA registration number in a prominent place on the website, differentiating itself from other CES devices. Quackwatch published a review of these technologies several years ago, last revised January 20, 2008, including links to the FDA warning letters from 2004 for implied claims and recall from 2007 for peak voltage test difficulties, yet the technology continues to be advertised. ${ }^{273}$

If a hazard threshold for regulation is the accepted threshold, ${ }^{274}$ then relative neglect in this area is to be accepted for products that pose little direct risk. But as these technologies improve, it is likely that these products

\footnotetext{
273 Stephen Barrett, Dubious Claims Made for NutriPax and Cranial Electrotherapy Stimulation, QUACKWATCH, http://www.quackwatch.org/01QuackeryRelatedTopics/ces.html (last updated Jan. 28, 2008), archived at http://perma.cc/F54F-MHHR; see also Warning Letter to Harold D. Stecker, supra note 269; Warning Letter to Daniel L. Kirsch, supra note 269.

274 See Katharine Van Tassel, Regulating in Uncertainty: Animating the Public Health Product Safety Net to Capture Consumer Products Regulated by the FDA that Use Innovative Technologies, Including Nanotechnologies, Genetic Modification, Cloning, and Lab Grown Meat, UNIV. CHI. LEGAL FORUM (2013).
} 
will become more effective, and pose more subtle risks than electrocution by the battery operated CES device or turning blue from silver exposure. A question raised by this scenario is whether a more nuanced view of regulation, such as one informed by novelty of the claim rather than specific hazard of the device, should be the threshold for a requirement of findings of efficacy and risk prior to marketing. ${ }^{275}$ While the FDA and FTC likely lack the resources to carry out such an expanded mission, transparency to the consumer about what they do and do not regulate would be within their means and a step in the right direction.

Perhaps it is unreasonable to charge agencies already burdened by substantive regulation (i.e. product authenticity and safety) to regulate messages as well. ${ }^{276}$ While risking slower innovation, in the area of selfimprovement technologies making health claims, there are perhaps some keyworded messages that should trigger demonstration of safety and efficacy before being made available in the marketplace. Given that there are currently no uniform definitions of brain health and brain fitness, defining these terms and developing scientifically based standards for consumer application would seem a reasonable place to begin. 277

What is likely to be more effective is improving consumer ability to evaluate claims made through more accessible and actionable information, be it through government websites, professional organization statements, or personal healthcare practitioners. In framing that which is normal, providing realistic information about the broad range of normal, providing credible and balanced information, and forcing the comparisons between new technologies and proven techniques to maintain health, we could potentially decrease consumer demand for these

275 Id.

276 See generally Quirk, supra note 175.

277 Nussbaum, supra note 194, at 7 ('With consumers' growing interest in cognitive health, there is a vital need to define brain health and to rely on scientifically based standards for consumer application."). 
speculative products, increase consumer sophistication, and therefore encourage the exit of untested products making unproven claims from the marketplace. Policy makers may also consider strategies that structure consumer choice, designate choice architects or nudge consumers toward better decisions. ${ }^{278}$ To this end, policymakers may need to consider both increasing the persuasive power of credible information and limiting the persuasive powers of entities attempting to provide unproven products.

\section{CONCLUSION}

The collective fascination with brains as the basis of behavior is second only to the lack of working knowledge about them. Progress, such as that promised by the Human Connectome Project and BRAIN, could do much to decrease consumer frustration and desperation that may increase the probability of turning to brain self-help products. In the interim, it is reasonable to predict that reporting related to these initiatives will contribute to ongoing public preoccupation with the brain.

Scientific discovery is big news. At a number of levels, public engagement is a driver of the discovery process. Researchers may have been passive conveyers of experimental results in times past, but, currently, there are increasing calls for scientists to anticipate potential applications or extensions of their work and welcome a dialogue that may influence the scientist's study design and help the scientist frame results in a way that minimizes the risk of distortion. ${ }^{279}$ How willing news outlets and other popular media are to be the vehicle of this discussion is a variable that has yet to be investigated.

Message matters. The brain is the current metaphor for humanity or personhood, and this rhetoric cannot be ignored or minimized; it must be managed. The brain is

278 SUNSTEIN \& THALER, supra note 181; UBEL, supra, note 181; Jon D. Hanson \& Douglas A. Kysar, Taking Behavioralism Seriously: The Product of Market Manipulation, 74 N.Y.U. L. REV. 630 (1999).

279 See O'Connor et al., supra note 35, at 225. 
truly not like any other organ in the body and it is humbling to continue to learn that on a daily basis. Research in the area needs to continue to mature in order to provide quality consumer information. Currently, most brain function studies are relatively small studies of association, yet the information considered most reliable for consumers would likely come from large prospective studies from which causation might be inferred.

Scientists, journalists, clinicians and experts of all types have a responsibility to communicate brain-science findings to the public using clear and accurate language. While the usually conservative and conditioned language of science is not the stuff of great headlines or sound bites, to do otherwise is a disservice to the public, the science and the professions. Enhancing consumer safety will likely involve some level of self-regulation of claims by scientists, journalists, and commercial entities. Amongst the information offered to consumers should be mandatory disclosure of whether, and how, the technology in question changes brain function when compared to traditional activities used to achieve the same results such as exercise. Even in minimal risk claims, some kind of proof of efficacy and screening of products making brain claims on a premarket basis should be undertaken because of the amount of current misinformation, rhetorical power of brain images, number of products being introduced, and prior abuses. Errors affecting the brain could be costly and difficult to correct as this complex system is poorly understood at best. The risk-benefit analysis will, almost by definition, be incomplete. The information that consumers need in order to make better decisions includes the high level of complexity of brain science, limitations of both science and current products, and a frame for understanding the wide range of normal brain function. In prior studies, showing consumers realistic information and pointing out common mistaken biases resulted in improved decision making.

Leaving consumers with the notion that a brain that "lights up" is human, and one that does not is somehow less than human, is neither accurate nor useful. As a derivative, 
placing a burden on consumers to maximize their brains or fall ill ignores the realities that illness may occur no matter how "fit" a brain is, and decisions made about the expenditure of brainpower are likely more important than how much power brains generate. Everything is a trade off. Perhaps mandatory funding of independent studies and consumer education programs by brain self-improvement product authors, marketers, suppliers, manufacturers, and producers would be an important first step in being accountable to the public for claims made. It could result in real changes within the industries involved and provide ideas, data, or models for meaningful regulation.

The lack of objective benchmarks for the outcomes of interest to consumers in brain science makes it difficult to evaluate claims and outcomes. Regulation in the face of this level of scientific indeterminacy is no easy matter, but providing credible and balanced information in an accessible fashion and barring the frankly preposterous claim should be at least tentative goals. In short, we can trust the informed consumer with his or her brain if we provide accessible, credible, understandable, and, where appropriate, actionable information that is consistent across news, entertainment, and self-help outlets. 